\title{
Article \\ Ecological and Health Risk Assessment of Potential Toxic Elements from a Mining Area (Water and Sediments): The San Juan-Taxco River System, Guerrero, Mexico
}

\author{
Edith Rosalba Salcedo Sánchez ${ }^{1, *}$, Juan Manuel Esquivel Martínez ${ }^{1} \mathbb{D}$, Manuel Martínez Morales ${ }^{2}$, \\ Oscar Talavera Mendoza ${ }^{1}$ and María Vicenta Esteller Alberich ${ }^{3}$ (D)
}

1 Escuela Superior de Ciencias de la Tierra, Universidad Autónoma de Guerrero, Taxco el Viejo 40323, Mexico; jmesquivel@conacyt.mx (J.M.E.M.); otalavera.uagro@gmail.com (O.T.M.)

2 Instituto Mexicano de Tecnología del Agua, Jiutepec 62550, Mexico; manuelm@tlaloc.imta.mx

3 Instituto Interamericano de Tecnología y Ciencias del Agua (IITCA), Universidad Autónoma del Estado de Mexico, Toluca 50120, Mexico; mvestellera@uaemex.mx

* Correspondence: edithsalcedos@gmail.com

check for

updates

Citation: Salcedo Sánchez, E.R.;

Martínez, J.M.E.; Morales, M.M.;

Talavera Mendoza, O.; Alberich, M.V.E. Ecological and Health Risk Assessment of Potential Toxic

Elements from a Mining Area (Water and Sediments): The San Juan-Taxco River System, Guerrero, Mexico. Water 2022, 14, 518. https://doi.org/ $10.3390 / w 14040518$

Academic Editor: Alban Kuriqi

Received: 24 December 2021

Accepted: 30 January 2022

Published: 9 February 2022

Publisher's Note: MDPI stays neutral with regard to jurisdictional claims in published maps and institutional affiliations.

Copyright: (C) 2022 by the authors. Licensee MDPI, Basel, Switzerland. This article is an open access article distributed under the terms and conditions of the Creative Commons Attribution (CC BY) license (https:// creativecommons.org/licenses/by/ $4.0 /)$

\begin{abstract}
The San Juan-Taxco River system is situated in the Taxco mining district, which is a wellknown international producer of silver, jewelry and precious metal handicrafts. The population and biota in the area have been affected by inappropriate disposal of anthropogenic activities that pollute the hydric resources and threaten their health and sustainability, since the inhabitants use the groundwater and river water for human consumption, domestic water supply and irrigation. This study was conducted to assess the pollution in the river system, human health implications and ecological risk in the aquatic environment (groundwater, surface water and superficial sediment). This evaluation was done on the base of hydrochemical, textural, mineralogical and geochemical analysis supported by calculation of human health risk using chronic daily intake (CDI), hazard quotient (HQ) and hazard index $(\mathrm{HI})$ with environmental and geochemical indices for ecological risk evaluation. The health risk assessment indicated increasing non-health carcinogenic risk to the exposed population to the river water and dug wells $(\mathrm{HI}>1)$, and thus, these resources are not recommended for human consumption, domestic activities and prolonged ingestion. The results demonstrated a high degree of pollution due to toxic elements and geochemical indices. The Pollution Load Index indicated potential risk that will cause harmful biological effects in the riverine environment.
\end{abstract}

Keywords: PTE; water quality; health risk assessment; ecological risk assessment; sediment; contamination factor; pollution load index; enrichment factor

\section{Introduction}

Potential Toxic Elements (PTE) pollution in the fluvial system is one of the major threats for aquatic life and human population due to the abundance, persistence, inherent toxicity, non-degradability, ubiquity, bioaccumulation and biomagnification in the food chain [1-3]. The concentration of these toxic elements as heavy metals has increased in the environment due to their anthropogenic inputs. Numerous rivers and aquifers have been polluted with PTE from industrialization processes and mining activities, especially from the inappropriate disposal of wastewater and mine tailings, resulting in negative effects $[4,5]$. PTE persist in the environment and can remain for a very long time; they can potentially accumulate and concentrate in aquatic organisms and cause serious harms and finally exhibit high toxicity and bioaccumulation features. A toxic effect is directly linked to human health through the food chain and drinking water resources [6-8].

Risk assessment is a method of evaluate the impacts of pollutants [9] and can be separated into human health risk assessment and ecological risk assessment according to the different protection targets $[9,10]$. Several studies have developed an integral assessment 
of water quality linked to human health and potential risks posed by PTE in aquatic environments [8]. Some PTE, such as $\mathrm{Cu}, \mathrm{Co}, \mathrm{Zn}, \mathrm{Fe}, \mathrm{Ca}, \mathrm{Se}, \mathrm{Ni}$ and $\mathrm{Mn}$, are beneficial to humans at low concentrations, but intake of some others, namely $\mathrm{As}, \mathrm{Cd}, \mathrm{Pb}$ and $\mathrm{Hg}$, are highly poisonous to humans, even at a low concentration. Human health risks will be increased due to the intake of excess PTE contents through three pathways: inhalation, oral ingestion and dermal absorption; the ingestion and dermal absorption routes are considered as more common for the accumulation of those toxic metals into the human body $[5,11]$. Many studies have focused on the ecological risk assessment of PTE in sediments $[2-4,6,7,12,13]$. Sediments are an appropriate indicator of fluvial ecosystem health due to its main role in transport and storage of pollutants and its peculiarity to release them to the water column [3].

The San Juan-Taxco River system (Guerrero, Mexico) represent a key resource in terms of providing water for drinking supply, agricultural activities and ecosystem services [14-16]. The mining industry, the increase of jewelry and handmade manufacturing workshops and population growth have caused serious pollution in this area [14,17]. Several studies in the region refer the presence PTE as Pb, As, Zn and Fe in the San Juan-Taxco River that exceeded the aquatic life criteria and the presence of $\mathrm{Pb}$ concentrations in human blood [14,16-18]. However, these studies have not integrated the effects from sediment, river water and groundwater on human health. There has not been performed a human health risk assessment or an ecological risk assessment and they can be considered diagnostic studies. Therefore, the difference of this investigation is to obtain a complete perspective of ecological and human health risk and impact of mining and jewelry on the San Juan-Taxco River system to improve the hydric management.

The specific objectives of this study are as follows: (1) to analyze the pollution status by PTE in the water and sediments of the San Juan-Taxco River system; (2) to assess the health risk in two population groups (adults and children) using the chronic daily intake, hazard quotient and hazard indices in river water and dug wells; (3) to evaluate the ecological risks using geochemical indices. This study provides a more profound comparison of PTE pollution in this river system for health risk assessment and the basis for better resources management from an ecological health perspective.

\section{Study Area}

The San Juan-Taxco River system belongs to the Middle Balsas Basin [19]. It is located in the Taxco and Iguala municipalities in the northern part of the state of Guerrero within the mining district of Taxco (Mexico) Figure 1. In Taxco, the climate is warm and subhumid with an annual average temperature of $21.9^{\circ} \mathrm{C}$; the warmest month is April with a mean temperature of $24^{\circ} \mathrm{C}$ and the coolest month is December with a mean of $20.3^{\circ} \mathrm{C}$. Precipitation is in the order of $1000 \mathrm{~mm} /$ year; the rain is concentrated in the period from June to October with maximum values of $254 \mathrm{~mm}$ in September, and the driest month is February, with $7.6 \mathrm{~mm}[14,19]$. The Iguala climate is warm sub-humid. The annual mean temperature is $26.1{ }^{\circ} \mathrm{C}$, with a maximum of $38{ }^{\circ} \mathrm{C}$ and a minimum of $14{ }^{\circ} \mathrm{C}$; the warmest months are April and May and the coolest months are December and January. The precipitation is moderate during June to September, with annual mean precipitation of $1100 \mathrm{~mm}$ /year, with maximum values of $226 \mathrm{~mm}$ in July, and the driest month is March, with $4.2 \mathrm{~mm}$ of precipitation [19].

Intensive mining produced large quantities of liquid and solid mining wastes containing EPT [15-17]. Historical solid wastes were buried or re-worked during the 20th century, but modern (1940 to present) wastes are accumulated in tailings dumps (Antonio, El Fraile, La Concha, El Solar, Guerrero I, Guerrero II and Los Jales, etc.), which contain moderately to highly oxidized material, sulfides and PTE, such as lead, barium, cadmium, zinc, iron, arsenic and strontium. These waste dumps were deposited on rocks of the Mexcala and Taxco Schist formations [16]. These formations are considered essentially impermeable units, although secondary porosity can be locally important. These characteristics prevent 
the infiltration of large volumes of Acid Mining Drainage (AMD) to aquifers, but enable surface drainage of metal-rich leachates, affecting the quality of effluent water $[14,16]$.

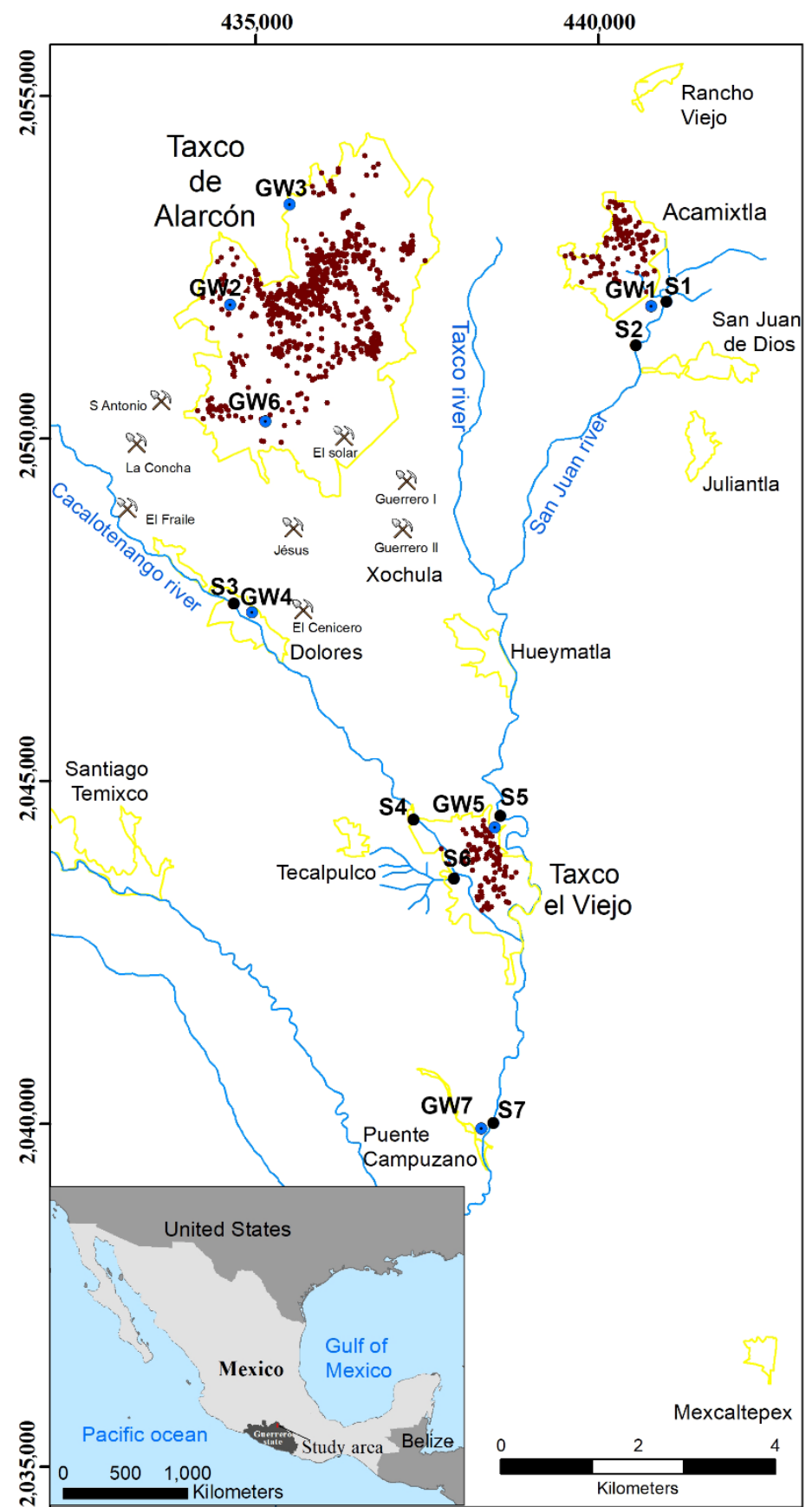

\section{Legend}

- Sampling point of river (water and sediments) (S1-S7)

- Sampling point of groundwater (springs and wells) (GW1-GW7)

- Handicraft and jewelry workshops

Q Tailings

- River

Locality

Study area

Projection

WGS84 UTM 14N

$\hat{N}$

Figure 1. Map of the sampling points (groundwater, river water and fluvial sediment) and location of mining tailings and handicrafts and jewelry workshops in the San Juan-Taxco River system.

This district has been recognized for years of mining and processing of precious metals since pre-Hispanic times until the closure of the mining activities (2009). At present, it is a famous touristic destination and international producer of precious metals handcrafts and jewelry [20]. The extraction of silver was the main activity of Taxco region, leading the inhabitants to undertake the task of working this metal as artisans [20]. The manufacture of jewelry and handicrafts became a key source of income in the region after the closure of the mines; this local industry has been developed through small workshops, which were diversified, including different processes of raw materials besides silver (Ag), such 
as alpaca $(\mathrm{Zn}-\mathrm{Cu}-\mathrm{Ni})$, brass $(\mathrm{Cu}-\mathrm{Zn})$, tumbaga $(\mathrm{Cu}-\mathrm{Au})$, for local and international trade. In 2019, 1085 workshops were officially recorded in the municipality of Taxco de Alarcon; these are mainly distributed in Taxco, Acamixtla and Taxco el Viejo localities inside the region (Figure 1) [21].

The metal processing has brought negative impacts on natural resources, with rivers being the most affected resources by the waste from these activities [16]. The San Juan-Taxco River system is composed of three rivers. The San Juan (length of $10 \mathrm{~km}$ ), Cacalotenango (length of $45 \mathrm{~km}$ ) and Taxco (length of $29.3 \mathrm{~km}$ ) rivers jointly discharge at the southern portion of the city of Taxco, also in the town of Taxco el Viejo, forming the Iguala or Cocula River (length $75 \mathrm{~km}$ ), and finally discharge into the Infiernillo reservoir [14,17].

The San Juan River receives wastewater from nearby towns, as well as chemical waste from silversmiths for the manufacture of silver crafts and mining tailings [22]. The Cacalotenango River receives mine waste from La Concha and El Fraile tailings, as well as urban wastewater without treatment [23]. The Taxco River receives mine waste from several tailing piles along its flow, chemical waste from silversmiths and untreated urban wastewater $[14,15]$.

\section{Geological and Hydrogeological Setting}

The Figure 2 summarized the geological map of the San Juan-Taxco River system showing the lithology. The bedrock in the area consists of Lower Cretaceous metamorphic rocks of the Taxco Schist Formation, Albian-Cenomanian limestone of the Morelos Formation, Upper Cretaceous sandstone and shale of the Mexcala Formation, Lower Tertiary red beds of the Balsas Formation and Middle Tertiary acidic volcanics of the Tilzapotla Formation $[15,16]$.

Mineralization structures are 1 to $3 \mathrm{~m}$ wide, although a few reach $10 \mathrm{~m}$, and 700 to $2000 \mathrm{~m}$ long, these structures appear as hydrothermal veins, replacement ores and stockworks hosted in limestones of the Morelos and Mexcala formations, and more rarely in the Taxco Schists and Balsas formations [16]. The San Juan-Taxco River system is part of the recharge zone of the regional aquifer (Buenavista and Iguala aquifers); this zone is immersed in a mountainous region with a rugged in portion of Taxco municipality and the Iguala valley. Therefore, the population uses surface runoff, dug wells and springs that are distributed throughout the region for drinking water, domestic consumption, agriculture and livestock [24].

The regional aquifer is composed by rhyolites from Tilzapotla Formation, gravels and sandstones from Balsas Group and limestones from Morelos Formation. The storage section of the groundwater is made up of the alluvial and fluvial sediments, such as clay, silt, sand and gravels, in the Iguala Valley. The groundwater drains into the lower parts of the study area, a portion of this water discharges into the main streams and another portion is released as a groundwater flow into the Tuxpan Lake [24]. 


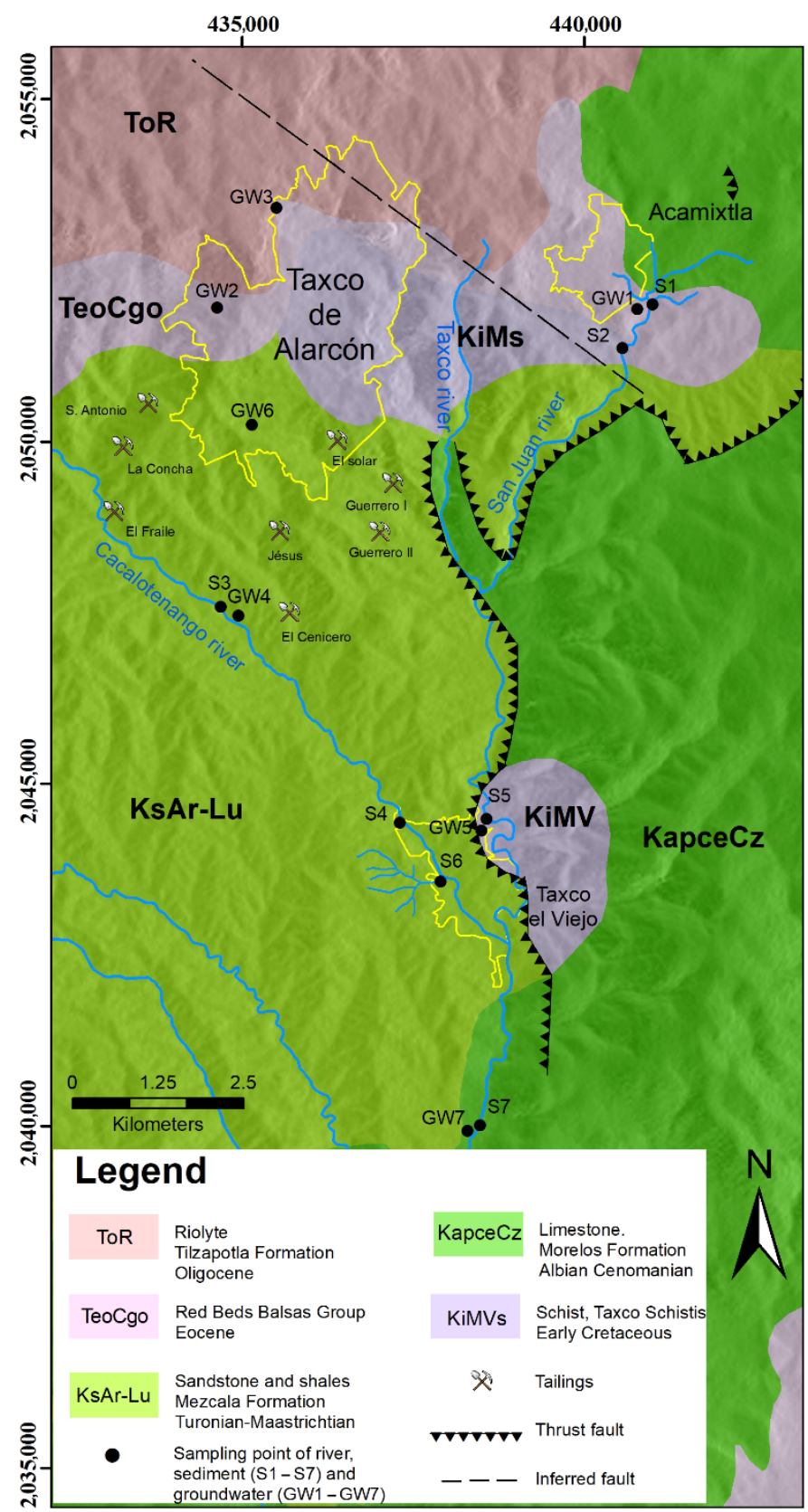

Figure 2. Geological map of the San Juan-Taxco River system.

\section{Materials and Methods}

\subsection{Sample Collection and Analytical Procedure}

For this analysis, a total of 21 samples were taken; seven groundwater (two dug wells and five springs), seven river water and seven surface sediment samples were collected in the dry season on May of 2019 to reduce the dilution of the effect of PTE concentrations in the rainy season. These samples were taken from the San Juan River system before its confluence with Taxco River, along the Cacalotenango and Taxco rivers and above and below their confluence, as shown Figure 1. The selection of the sampling points was made considering the spatial and geographical distribution along the river system, the proximity to handicraft and jewelry workshops sites and accessibility of the sites.

Water samples were collected in $1 \mathrm{~L}$ polyethylene sampling bottles, pre-cleaned with $10 \% \mathrm{HNO}_{3}$, soaked overnight and rinsed thoroughly with Milli-Q water. The $\mathrm{pH}$, temperature, electrical conductivity (EC) and total dissolved solids (TDS) measurements were performed during sampling using a Hanna multi-parametric sonde. For PTE analysis, 
the water samples were filtered using $0.40-0.45 \mu \mathrm{m}$ membrane, acidified to $\mathrm{pH}<2$, with $\mathrm{HNO}_{3}$ at the time of collection to prevent element precipitation and adsorption to the surface of the container during transportation; the samples were then stored at a suitable temperature awaiting analysis (water $<4{ }^{\circ} \mathrm{C}$ ). The levels of $\mathrm{Al}, \mathrm{As}, \mathrm{Ba}, \mathrm{B}, \mathrm{Cu}, \mathrm{Fe}, \mathrm{Pb}, \mathrm{Zn}$, $\mathrm{Mn}, \mathrm{Ni}$ and $\mathrm{Cd}$ in water samples (surface water and groundwater) were analyzed by Inductively Coupled Plasma Emission Spectrometry (ICP-OES) and Liquid Chromatography high performance (HPLC) at the Laboratory of Geosciences at the National Autonomous University of Mexico (UNAM).

The sediment samples were collected using polyethylene spoons and bags to determine physical and geochemical characteristics, kept at $4{ }^{\circ} \mathrm{C}$ until further analysis. In the laboratory, sediment samples were air-dried and ground to a fine powder with an agate mortar and then sieved through a 230 ASTM mesh at the Laboratory of Nutrition and Plant Physiology Campus Tuxpan of the Faculty of Agricultural and Environmental Sciences of the Autonomous University of Guerrero (UAGro).

For determining the PTE content (Al, As, Ba, B, Cu, Fe, Pb, Zn, Mn, Ni and Cd), drysediment samples were digested in a 1:1 $\mathrm{HCl}$ : $\mathrm{HNO} 3$ mixture inside a CEM MarxXpress microwave oven [25]. The PTE quantification was conducted using an Inductively Coupled Plasma Optical Emission Spectrometer (ICP-OES) Thermo iCAP 6500 Duo in the Environmental Geosciences Laboratory of UNAM. The grain size analysis was carried out to determine the sediment textural classes according to the Unified Soil Classification System (USCS) [26]. The sediments were classified into gravel, sand, silt and clay. The characterization of mineralogical phases in sediment samples was determined by $\mathrm{X}$-ray diffraction, in a Bruker AXS D8 Advance diffractometer to identify the major minerals; this analysis was performed at the Geochemistry Laboratory of Regional School of Earth Sciences of the UAGro.

\subsection{Quality Controls and Calibration Curves for Analytical Equipment}

Analytical blanks were implemented throughout the field campaign and analytical process. Replicate samples and standards were processed to determine the precision, and spiked samples were employed to determine accuracy.

The analysis by ICP-OES was made using two calibration curves with six standards, which were prepared from certified mono-elemental standards from the Inorganic Ventures brand and an ICP-200.7 multi-element standard from the High Purity Standards brand. Two types of blanks are analyzed, the calibration blank and the reagent blank, in addition to analyzing three laboratory control samples (MCL), all made from certified standards with traceability to NIST.

HPLC calibration curve is carried out with a standard certificate from Inorganic Ventures IF-FAS-1A, which consists of seven concentrations, and for the drift control of the instrument, it is carried out by means of a Laboratory Control Sample (MCL) prepared from the standard certificate Seven Anion Standard of Dionex, which was analyzed every 10 samples.

The acid digestion of aqueous samples and sediment is carried out with a microwave MARS Xpress CEM, for its calibration, it uses a blank and a sample added with a known concentration of a high purity certified standard (QCS-26) analyzed by ICP-OES.

To establish laboratory accuracy and precision, the limits of the results were calculated from the upper and lower control limits based on the mean and standard deviation of the percent recovery for at least 20 data points.

\subsection{Non-Parametric Statistics}

All datasets were checked for outliers and assessed for normality (surface water, groundwater and sediments), first objectively using a Shapiro-Wilk test. The calculations were performed using Excel. 


\subsection{Health Risk Assessment}

Risk assessment is a methodology which identifies, characterizes and analyzes the toxic element to qualify the adverse effects in a specified time and estimates risk levels [27]. This approach was applied to identify the exposure and tendency of toxic elements in San Juan-Taxco River system's water with reference to the human body. There are two central ways of metal exposure and pathways in human organism, either through water consumption as ingestion or through dermal absorption [7].

The health risk assessment was computed through the chronic daily intake (CDI; $\mathrm{mg} \mathrm{kg}^{-1} /$ day). It helps in assessing the health risk caused by exposure to PTE (heavy metals) through different pathways. For this study, ingestion and dermal exposure (CDI) were computed by Equations (1) and (2) [27]. The receptors were categorized into two categories, infants ( $<6$ years old children) and adults ( $<30$ years old).

$$
\begin{gathered}
C D I_{\text {ingestion-water }}=\frac{E C \cdot I R \cdot E F \cdot E D}{B W \cdot A T} \\
C D I_{\text {Dermal }}=\frac{E C \cdot S A \cdot A F \cdot A B D S_{d} \cdot E T \cdot E D \cdot C F}{B W \cdot A T}
\end{gathered}
$$

where $E C$ is the concentration of TEs in the water, $I R$ is the ingestion rate ( $\left.\mathrm{L} \mathrm{day}^{-1}\right), E F$ is the exposure frequency (days/year), $E D$ is the exposure duration (years), $B W$ is the average body weight $(\mathrm{kg}), A T$ is the averaging time (days), $S A$ is the surface area of skin in contact $\left(\mathrm{cm}^{2}\right), A F$ is the skin adherence factor, $A B S D S_{d}$ is the dermal absorption factor $E T$ is the exposure $\left(\mathrm{h} \mathrm{day}^{-1}\right), C F$ is the conversion factor $\left(\mathrm{kg} \mathrm{mg}^{-1}\right)$ and $E T$ is the exposure $\left(\mathrm{h} \mathrm{day}^{-1}\right)$ (Table 1$)$.

\begin{tabular}{|c|c|c|c|c|c|c|c|}
\hline Symbol & Name & Unit & $\begin{array}{c}\text { Recommended } \\
\text { Values }\end{array}$ & Symbol & Name & Unit & $\begin{array}{l}\text { Recommended } \\
\text { Values (Adult) }\end{array}$ \\
\hline $\mathrm{Cw}$ & $\begin{array}{c}\text { Element } \\
\text { concentration }\end{array}$ & $\mathrm{mg} \mathrm{L}^{-1}$ & & SA & $\begin{array}{c}\text { exposed skin } \\
\text { area }\end{array}$ & $\mathrm{cm}^{2}$ & $\begin{array}{l}\text { adult } 5700 \text {, } \\
\text { child } 28,00^{*}\end{array}$ \\
\hline IR & Ingestion rate & $\mathrm{L} \mathrm{day}^{-1}$ & $\begin{array}{l}\text { adult } 2.5 \\
\text { child: } 0.78\end{array}$ & $\mathrm{AF}$ & $\begin{array}{c}\text { adherence } \\
\text { factor }\end{array}$ & - & 0.07 * \\
\hline $\mathrm{EF}$ & $\begin{array}{l}\text { Exposure } \\
\text { frequency }\end{array}$ & day $y^{-1}$ & 350 & ABSd & $\begin{array}{l}\text { dermal } \\
\text { absorption } \\
\text { fraction }\end{array}$ & - & 0.03 \\
\hline ED & $\begin{array}{l}\text { Total exposure } \\
\text { duration }\end{array}$ & year & $\begin{array}{l}\text { adult } 30 ; \\
\text { child } 6\end{array}$ & ET & $\begin{array}{l}\text { exposure } \\
\text { time }\end{array}$ & $\mathrm{h} \mathrm{day}^{-1}$ & 0.58 \\
\hline BW & $\begin{array}{c}\text { Average body } \\
\text { weight }\end{array}$ & & $\begin{array}{c}\text { Adult } 52 \mathrm{~kg} \\
\text { children } 15 \mathrm{~kg}\end{array}$ & CF & $\begin{array}{l}\text { conversion } \\
\text { factor }\end{array}$ & $\mathrm{kg} \mathrm{mg}^{-1}$ & $10^{-2+}$ \\
\hline AT & $\begin{array}{c}\text { Average } \\
\text { exposure time }\end{array}$ & day & $\begin{array}{l}\text { adult } 10,950, \\
\text { child } 2190\end{array}$ & RfDingestion & $\begin{array}{c}\text { Reference } \\
\text { Dose of PTEs }\end{array}$ & $\begin{array}{c}\mathrm{mg} \mathrm{kg}^{-1} \\
\text { day }^{-1}\end{array}$ & $\begin{array}{c}\text { RfDingestion } \\
\mathrm{Al}=1, \mathrm{Cu}=0.04 \\
\mathrm{Fe}=0.7, \mathrm{Mn}=0.00096 \\
\mathrm{~Pb}=0.00042 \\
\mathrm{Zn}=0.06, \mathrm{As}=0.0003 \\
\mathrm{RfDDerlmal} \\
\mathrm{Al}=0.01, \mathrm{Cu}=0.00184, \\
\mathrm{Fe}=0.14, \mathrm{Mn}=0.024 \\
\mathrm{~Pb}=0.0035 \\
\mathrm{Zn}=0.3, \mathrm{As}=0.003, \\
\mathrm{Ba}=20\end{array}$ \\
\hline
\end{tabular}

Table 1. Exposure factors used in chronic daily intake (CDI) estimation for non-carcinogenic risk. 
The hazard quotient (ingestion and dermal) and hazard index (HI) are computed by Equations (3) and (4) [27]:

$$
\begin{aligned}
H Q_{\text {ingestion }} & =\frac{C D I_{\text {ingestion }}}{R f D_{\text {ingestion }}} \\
H Q_{\text {Dermal }} & =\frac{C D I_{\text {Dermal }}}{R f D_{\text {Dermal }}}
\end{aligned}
$$

where RfD denotes the reference dose (ingestion and dermal) based on the guidelines of the US Environmental Protection Agency [28] and for health risk assessment calculation (RfD differs for each PTE). The hazard index (HI) represents the cumulative non-carcinogenic risk. It is the sum of HQs for similar toxic effects and all pathways. It can also be calculated by Equation (5):

$$
\mathrm{HI}=\sum H Q_{i}=H Q(\text { ingestion })+H Q(\text { dermal })
$$

where $i$ is the HQ value of each element. In the context of human health, the $H I$ values $<1$ are low risk, while the values $>1$ are high risk with long-term health hazard effects [5].

\subsection{Assessment of PTE in the San Juan-Taxco River System (Water and Sediment)}

Water quality was evaluated according to the criteria established for human consumption by the World Health Organization [29]. PTE risk in sediments was assessment using Sediment Quality Guidelines (SQG), probable effect level threshold (PEL), threshold effect concentration (TEC) and probable effect concentration (PEC) [30-32]. These guidelines allowed a simple, comparative mean for assessing the potential risk of pollution in a fluvial aquatic ecosystem.

\subsection{Assessment of PTE Enrichment in Sediments}

\subsubsection{Geoaccumulation Index (Igeo)}

The Igeo allows for the assessment of PTE sediment contamination and can be used to evaluate the environmental pollution status compared with background values $[13,33,34]$. The Igeo is calculated by Equation (6):

$$
\text { Igeo }=\frac{\log _{2}\left(C_{n}\right)}{1.5\left(B_{n}\right)}
$$

where $C_{n}$ is the content of elements in the sediment samples, $B_{n}$ is the concentration of geochemical background for the same elements $(n)$ and factor 1.5 is the background matrix correction factor due to lithological variations. The Igeo, according to Muller [33], includes seven classes, summarized in Table 2 and the background values used are presented in Table $3[35,36]$.

\subsubsection{Enrichment Factor (EF)}

Enrichment factor $(\mathrm{EF})$ is an indicator that reflects the degree of anthropogenic pollution [37]. The EF is calculated using the relationship in Equation (7):

$$
E F=\frac{\left(\frac{\text { Metal }}{A l}\right) \text { sample }}{\left(\frac{\text { Metal }}{A l}\right) \text { background }}
$$

In this case, aluminum $(A l)$ was employed as the reference element for geochemical normalization; this element in sediments is useful to eliminate the effect of grain size, since it is a major element and exhibits relatively small content variations and a large distribution. The interpretation provided by Malvandi [2] from the EF values was used for this study and is presented in Table $2[2,38]$. 
Table 2. Enrichment and contamination categories base don Igeo, EF, CF, PLI and RI.

\begin{tabular}{|c|c|c|c|c|c|}
\hline \multicolumn{2}{|c|}{ Geoaccumulation Index (Igeo) } & \multicolumn{2}{|c|}{$\begin{array}{l}\text { Enrichment Factor } \\
\text { (EF) }\end{array}$} & \multicolumn{2}{|c|}{$\begin{array}{l}\text { Contamination Factor } \\
\text { (CF) }\end{array}$} \\
\hline Value & Categorization & Value & Categorization & Value & Categorization \\
\hline$<0$ & Unpolluted & $<1$ & $\begin{array}{l}\text { indicates no } \\
\text { enrichment }\end{array}$ & $<1$ & low contamination \\
\hline $0-1$ & $\begin{array}{l}\text { Pristine to } \\
\text { moderately } \\
\text { contaminated }\end{array}$ & $3-5$ & $\begin{array}{l}\text { moderate } \\
\text { enrichment }\end{array}$ & $1-3$ & $\begin{array}{c}\text { moderate } \\
\text { contamination }\end{array}$ \\
\hline $1-2$ & $\begin{array}{c}\text { Moderately } \\
\text { contaminated }\end{array}$ & $5-10$ & $\begin{array}{c}\text { moderately } \\
\text { severe enrichment }\end{array}$ & $3-6$ & $\begin{array}{l}\text { considerable } \\
\text { contamination }\end{array}$ \\
\hline $2-3$ & $\begin{array}{l}\text { Moderately to } \\
\text { strongly } \\
\text { contaminated }\end{array}$ & $10-25$ & severe enrichment & $>6$ & $\begin{array}{l}\text { very high } \\
\text { contamination }\end{array}$ \\
\hline $3-4$ & $\begin{array}{c}\text { Strongly } \\
\text { contaminated }\end{array}$ & $25-50$ & $\begin{array}{l}\text { Very severe } \\
\text { enrichment }\end{array}$ & & \\
\hline $4-5$ & $\begin{array}{l}\text { Strongly to } \\
\text { extremely strongly } \\
\text { contaminated } \\
\text { extremely strongly } \\
\text { contaminated }\end{array}$ & $>50$ & $\begin{array}{c}\text { Extremely } \\
\text { severe enrichment }\end{array}$ & & \\
\hline \multicolumn{2}{|c|}{ Potential ecological risk factor $\left(E_{r}^{i}\right)$} & \multicolumn{2}{|c|}{ Potential ecological risk index (RI) } & \multicolumn{2}{|c|}{ Pollution Load Index (PLI) } \\
\hline Value & Categorization & Value & Categorization & Value & Categorization \\
\hline$<40$ & low ecological risk & $<150$ & low ecological risk & $<1$ & Unpolluted \\
\hline $40-80$ & $\begin{array}{c}\text { moderate ecological } \\
\text { risk }\end{array}$ & $150-300$ & $\begin{array}{c}\text { moderate ecological } \\
\text { risk }\end{array}$ & $1-2$ & Moderately polluted \\
\hline $80-60$ & $\begin{array}{l}\text { appreciable } \\
\text { ecological risk }\end{array}$ & $300-600$ & $\begin{array}{l}\text { considerable } \\
\text { ecological risk }\end{array}$ & $2-3$ & Heavily polluted \\
\hline $160-320$ & high ecological risk & $>600$ & $\begin{array}{l}\text { very high ecological } \\
\text { risk }\end{array}$ & $>3$ & Extremely polluted. \\
\hline$>320$ & $\begin{array}{l}\text { serious ecological } \\
\text { risk }\end{array}$ & & & & \\
\hline
\end{tabular}

\subsubsection{Contamination Factor (CF)}

Sediment contamination was also assessed by using the contamination factor (CF) and degree of contamination. The $\mathrm{CF}$ index values were calculated by dividing the concentration of each PTE in the sediment by the baseline or background values [39]. CF values were explained according to Hakanson [39] in Equation (8) and summarized in Table 2:

$$
C F=\frac{C_{\text {heavy metal }}}{C_{\text {background values }}}
$$

\subsubsection{Pollution Load Index (PLI)}

Pollution load index (PLI) represents the number of times by which the toxic element concentrations in the sediment exceeds the background concentration, and gives a summative indication of the overall level of PTE toxicity in a particular sample. For the entire sampling site, PLI has been estimated by the n-root from the product of $n \mathrm{CF}$ of the studied elements included (Equation (9)):

$$
P L I=\left(C F_{1} \times C F_{2} \times C F_{3} \times \ldots \ldots \times C F_{n}\right)^{n}
$$

The PLI is a multi-elemental index used to assess the degree of PTE pollution and, hence, to evaluate the environmental quality. The PLI for the entire study area (Equation (10)) can be estimated using the same calculation principle for each sampling point; substituting the $\mathrm{CF}$ 
values for the PLI value of each point, it is determined as the nth root of the product of the $n$ CF (Contamination Factors) according to Tomlinson [40]:

$$
P L I_{\text {global }}=(P L I 1 \times P L I 2 \times P L I 3 \cdots . . \times P L I n)^{1 / n}
$$

The index permits a simple, comparative means for assessing PTE pollution levels. A PLI of $>1$ is contaminated, whereas $<1$ indicates no contaminated site [39]. Corami et al., (2020) [13] used other evaluation criteria for classifying the degree of contamination for PLI, as shown in Table 2.

Table 3. Potential Toxic Element concentrations (PTE in waters $\left(\mathrm{mg} \mathrm{L}^{-1}\right.$ ) compared with World Health Organization limits and sediment $\left(\mathrm{mg} \mathrm{kg}^{-1}\right)$ compared with background values [35,36], Sediment Quality Guideline values (SQGs), PEL, TEC and PEC.

\begin{tabular}{|c|c|c|c|c|c|c|c|c|c|c|c|c|c|c|c|c|}
\hline & Sites & Nature & $\mathrm{pH}$ & Al & As & B & Ва & $\mathrm{Cd}$ & Co & $\mathrm{Cr}$ & $\mathrm{Cu}$ & $\mathrm{Fe}$ & Mn & $\mathrm{Ni}$ & $\mathrm{Pb}$ & $\mathrm{Zn}$ \\
\hline \multirow{14}{*}{ 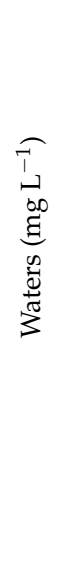 } & S1 & \multirow{7}{*}{$\begin{array}{l}\text { River } \\
\text { water }\end{array}$} & 6.8 & 0.0071 & <l.q. & 0.0223 & 0.0942 & $<$ l.q. & $<$ l.q. & $<$ l.q. & $<$ l.q. & 0.0137 & 0.0822 & $<$ l.q. & $<$ l.q. & 0.0191 \\
\hline & $\mathrm{S} 2$ & & 8.1 & 0.0084 & 0.0725 & 0.1173 & 0.1217 & $<$ l.q. & $<$ l.q. & $<$ l.q. & 0.0046 & 0.0755 & 0.3622 & $<$ l.q. & 0.0182 & 0.2335 \\
\hline & S3 & & 7.9 & 0.0912 & 0.0291 & 0.0159 & 0.1162 & $<$ l.q. & $<$ l.q. & $<$ l.q. & 0.0044 & 0.1759 & 0.1346 & $<$ l.q. & 0.0149 & 0.0573 \\
\hline & S4 & & 7.3 & 0.2525 & $<$ l.q. & $<$ l.q. & 0.1224 & $<$ l.q. & $<$ l.q. & $<$ l.q. & 0.0061 & 0.3164 & 0.0541 & $<$ l.q. & 0.0165 & 0.0858 \\
\hline & S5 & & 7.2 & 0.0455 & $<$ l.q. & 0.5284 & 0.0646 & $<$ l.q. & $<$ l.q. & $<$ l.q. & 0.0070 & 0.0396 & 0.5343 & 0.0181 & <l.q. & 0.0843 \\
\hline & S6 & & 7.2 & 0.0397 & $<$ l.q. & $<$ l.q. & 0.0722 & $<$ l.q. & $<$ l.q. & $<$ l.q. & $<$ l.q. & 0.0818 & 0.0073 & $<$ l.q. & $<$ l.q. & 0.0069 \\
\hline & S7 & & 8.1 & 0.0125 & $<$ l.q. & 0.5791 & 0.0914 & $<$ l.q. & $<$ l.q. & $<$ l.q. & 0.0078 & 0.0175 & 1.4482 & 0.0174 & $<$ l.q. & 0.0503 \\
\hline & GW1 & $\begin{array}{l}\text { Dug } \\
\text { well }\end{array}$ & 7.0 & 0.0183 & $<$ l.q. & $<$ l.q. & 0.081 & $<$ l.q. & $<$ l.q. & $<$ l.q. & 0.004 & 0.146 & 0.032 & $<$ l.q. & 0.0245 & 0.0770 \\
\hline & GW2 & \multirow{5}{*}{ Springs } & 6.6 & $<$ l.q. & $<$ l.q. & $<$ l.q. & 0.111 & $<$ l.q. & $<$ l.q. & $<$ l.q. & $<$ l.q. & $<$ l.q. & $<$ l.q. & $<$ l.q. & $<$ l.q. & $<$ l.q. \\
\hline & GW3 & & 6.7 & 0.0125 & $<$ l.q. & $<$ l.q. & 0.023 & $<$ l.q. & $<$ l.q. & $<$ l.q. & $<$ l.q. & $<$ l.q. & $<$ l.q. & $<$ l.q. & 0.0235 & 0.0053 \\
\hline & GW4 & & 8.2 & 0.1127 & $<$ l.q. & 0.017 & 0.048 & $<$ l.q. & $<$ l.q. & $<$ l.q. & $<$ l.c. & 0.021 & 0.009 & $<$ l.q. & <l.q. & 0.0149 \\
\hline & GW5 & & 7.2 & 0.0097 & $<$ l.q. & 0.068 & 0.081 & $<$ l.q. & $<$ l.q. & $<$ l.q. & 0.111 & 0.022 & 0.006 & $<$ l.q. & $<$ l.q. & 0.2442 \\
\hline & GW6 & & 6.9 & 0.0059 & $<$ l.q. & $<$ l.q. & 0.040 & $<$ l.q. & $<$ l.q. & $<$ l.q. & 0.010 & $<$ l.q. & $<$ l.q. & $<$ l.q. & $<$ l.q. & 0.0130 \\
\hline & GW7 & $\begin{array}{l}\text { Dug } \\
\text { well }\end{array}$ & 7.9 & 0.0135 & $<$ l.q. & $<$ l.q. & 0.069 & $<$ l.q. & $<$ l.q. & $<$ l.q. & $<$ l.q. & $<$ l.q. & $<$ l.q. & $<$ l.q. & $<$ l.q. & 0.0277 \\
\hline \multicolumn{2}{|c|}{ WHO (2008) } & & $6.5-8.5$ & 0.200 & 0.025 & 0.300 & 0.700 & & & 0.050 & 1.300 & 0.300 & 0.400 & & 0.010 & 3.000 \\
\hline$\overparen{T}$ & S1 & \multirow{7}{*}{$\begin{array}{c}\text { River } \\
\text { sediment }\end{array}$} & & $16,771.0$ & $<$ l.q. & 15.8 & 154.0 & 2.1 & 5.2 & 5.0 & 209.0 & $18,637.0$ & 231.0 & 18.7 & 35.6 & 351.0 \\
\hline 䎹 & $\mathrm{S} 2$ & & & $16,610.0$ & 39.3 & 16.8 & 151.0 & 1.8 & 6.1 & 2.5 & 68.3 & $20,009.0$ & 362.0 & 16.6 & 94.2 & 144.0 \\
\hline జ్ర & S3 & & & $18,313.0$ & 48.8 & 12.8 & 173.0 & 16.2 & 7.2 & $<$ l.q. & 78.4 & $20,526.0$ & 795.0 & 15.7 & 265.0 & 2008.0 \\
\hline$\stackrel{ \pm}{ \pm}$ & S4 & & & $20,303.0$ & 25.5 & 31.2 & 278.0 & 50.4 & 7.8 & $5.5^{1}$ & 393.0 & $20,614.0$ & 2710.0 & 111.0 & 244.0 & 4509.0 \\
\hline ฮี & S5 & & & $19,032.0$ & 24.7 & 15.9 & 104.0 & 5.5 & 7.2 & $<$ l.q. & 41.8 & $23,223.0$ & 334.0 & 18.6 & 160.0 & 967.0 \\
\hline : & S6 & & & $22,982.0$ & $<$ l.q. & 19.9 & 143.0 & 2.0 & 9.0 & 9.4 & 117.0 & $20,930.0$ & 105.0 & 24.2 & 13.9 & 142.0 \\
\hline ర్ల & S7 & & & $12,086.0$ & 21.3 & 13.8 & 88.0 & 9.4 & 6.3 & $<$ l.q. & 55.9 & $22,301.0$ & 660.0 & 20.0 & 189.0 & 1763.0 \\
\hline \multicolumn{2}{|c|}{ PEL a } & & & & $17 \mathrm{a}$ & & & $3.53 \mathrm{a}$ & & $90 \mathrm{a}$ & $196.6 \mathrm{a}$ & & & $75 \mathrm{a}$ & $91.3 \mathrm{a}$ & $314.8 \mathrm{a}$ \\
\hline \multicolumn{2}{|c|}{ TEC b } & & & & $9.79 \mathrm{~b}$ & & & $0.99 \mathrm{~b}$ & & $43.4 \mathrm{~b}$ & $31.6 \mathrm{~b}$ & & & $22.7 b$ & $35.8 \mathrm{~b}$ & $121 \mathrm{~b}$ \\
\hline \multicolumn{2}{|c|}{$\begin{array}{c}\text { PEC c } \\
\text { Background }\end{array}$} & & & & $33 c$ & & & $4.98 \mathrm{c}$ & & $111 \mathrm{c}$ & 149 c & & & $48.6 \mathrm{c}$ & $128 \mathrm{c}$ & $459 \mathrm{c}$ \\
\hline $\begin{array}{r}\text { Bacl } \\
\mathrm{v}\end{array}$ & $\begin{array}{l}\text { ound } \\
\text { les }\end{array}$ & & & 81,500 & 4.8 & 17 & 628 & 0.09 & 17.3 & 92 & 28 & 50,400 & 774 & 47 & 17 & 67 \\
\hline
\end{tabular}

Note: 1.q. (limit of quantification).

\subsubsection{Potential Ecological Risk Index (RI)}

The maximum contamination in sediments caused by PTE is screened by the Potential Environmental Risk Index (PERI or RI); this method is widely used to evaluate quantitatively the level of the ecological risk degree of PTE. This index was proposed by Hankson in 1980 [39] and it is founded on Sedimentation Theory. The RI value is computed following the formula (Equation (11)) [39]:

$$
R I=\sum_{i=1}^{n} E_{r}^{i}, \quad E_{r}^{i}=T_{r}^{i} x C F
$$

where $E_{r}^{i}$ is the potential ecological risk factor for a given contaminant $(i), T_{r}^{i}$ is the toxic response factor of each element, including $\mathrm{Cr}=2, \mathrm{Cu}=5, \mathrm{Cd}=30, \mathrm{As}=10$ and $\mathrm{Pb}=5[39]$, and $C F$ are the contamination factors, which have already been described above. This 
scheme not only assesses the pollution status in sediment, but also combines ecological and environmental effects with toxicology, providing a better evaluation of the potential risk of PTE contamination with the index level. $R I$ is a set of potential risks for each element, is an integrated potential environmental risk index for several PTEs and is classified based on the description summarized in Table 2.

\section{Results}

\subsection{Non-Parametric Statistics}

An exploratory analysis with Shapiro-Wilk's method to test the normality was applied to the concentration data. It was found that $\mathrm{Ba}, \mathrm{Fe}$ and $\mathrm{Zn}$ in surface water followed a normal distribution, with $\mathrm{R}^{2}$ values equal to $0.89,0.82$ and 0.81 , respectively; $\mathrm{Ba}$ in groundwater had a correlation coefficient of 0.97 . For sediments, $\mathrm{Al}$ and Ba followed the normal distribution, with $\mathrm{R}^{2}$ values of 0.97 and 0.87 , respectively. For other elements, some outliers were present in the data, which reduced the correlation coefficient. Those outliers were analyzed in the whole context of geographical distribution to correlate them with the presence or absence of an important source of pollution.

\subsection{Water}

\subsubsection{Hydrochemical Characterization}

$\mathrm{pH}$ is an important factor that influences the solubility of toxic elements (PTE) in water [11]; lower values of $\mathrm{pH}$ indicate higher solubility and vice versa. The $\mathrm{pH}$ values in the groundwater ranged from 6.75 to 8.1, and that in river water fluctuated from 6.16 to 8.2 (Table 3). In general, the $\mathrm{pH}$ varies in water from neutral to slightly alkaline, where the reactivity of PTE was low and their concentration loadings oscillated between low and high concentration. Almost all the collected samples of water (groundwater and river water) have detectable concentrations of PTE.

Water quality was assessed according to criteria established for human use and consumption by the World Health Organization [29]. In case of groundwater, $\mathrm{Al}, \mathrm{B}, \mathrm{Ba}, \mathrm{Cu}, \mathrm{Fe}$, $\mathrm{Mn}, \mathrm{Pb}$ and $\mathrm{Zn}$ were measured, and only $\mathrm{Pb}$ exceed the criteria $\left(0.03 \mathrm{mgL}^{-1}\right)$ for human use and consumption of the WHO in samples GW1 and GW3. Al, As, B, Ba, Cu, Fe, Mn, Pb and $\mathrm{Zn}$ were detected in the river water (Table 3).

Although Al was measured in all the samples, only S4 showed a concentration above the WHO limit of $0.2 \mathrm{mg} \mathrm{L}^{-1}$; two samples (S2 and S3) showed As concentrations above the WHO limit $\left(0.025 \mathrm{mg} \mathrm{L}^{-1}\right)$. B was present in S1, S2, S3, S5 and S7, but only in S5 and S7 did it exceed the recommended limit for human use and water consumption. Fe and Mn were detected in all the samples; S4 and S5 surpassed the WHO limit of $0.3 \mathrm{mgL}^{-1}$ for Fe and $\mathrm{Mn}$ was above the $0.4 \mathrm{mgL}^{-1}$ recommended limit for S7. On the other hand, $\mathrm{Ba}$ and $\mathrm{Zn}$ were found in all the samples, but were always below the WHO limits $(0.7$ and $3 \mathrm{mg} \mathrm{L}^{-1}$, respectively).

\subsubsection{Health Risk Assessment in Water Samples}

The potential health risk to human beings by water for human use and consumption was calculated by assessing the PTE concentration in water (groundwater and river water) and by assessing the pathways through which humans are exposed to these elements. In this study, non-carcinogenic risk was determined by estimating the daily intake index (CDI), which represents the daily exposure of a population to contaminants, hazard quotient (HQ), to estimate the non-carcinogenic risk by toxic elements, and cumulative hazard index (HI), to show the potential health risk possess by multiple elements, considering the additive effect of PTE in HQ were determined. The studied exposure pathways were ingestion and dermal absorption in children and the adult population; the receptors were categorized in children $(<6$ years old) and adults ( $>30$ years old).

CDI ingestion values for both groups were under limit $(<1)$ and at present poses no serious threat to human health, although Mn values were one of the highest values as 
compared with other PTE analyzed for both adults and child (in sample S7), though values of $\mathrm{Cu}$ were highest for children in sample GW5 (Figures 3 and 4).

\section{Ingestion}

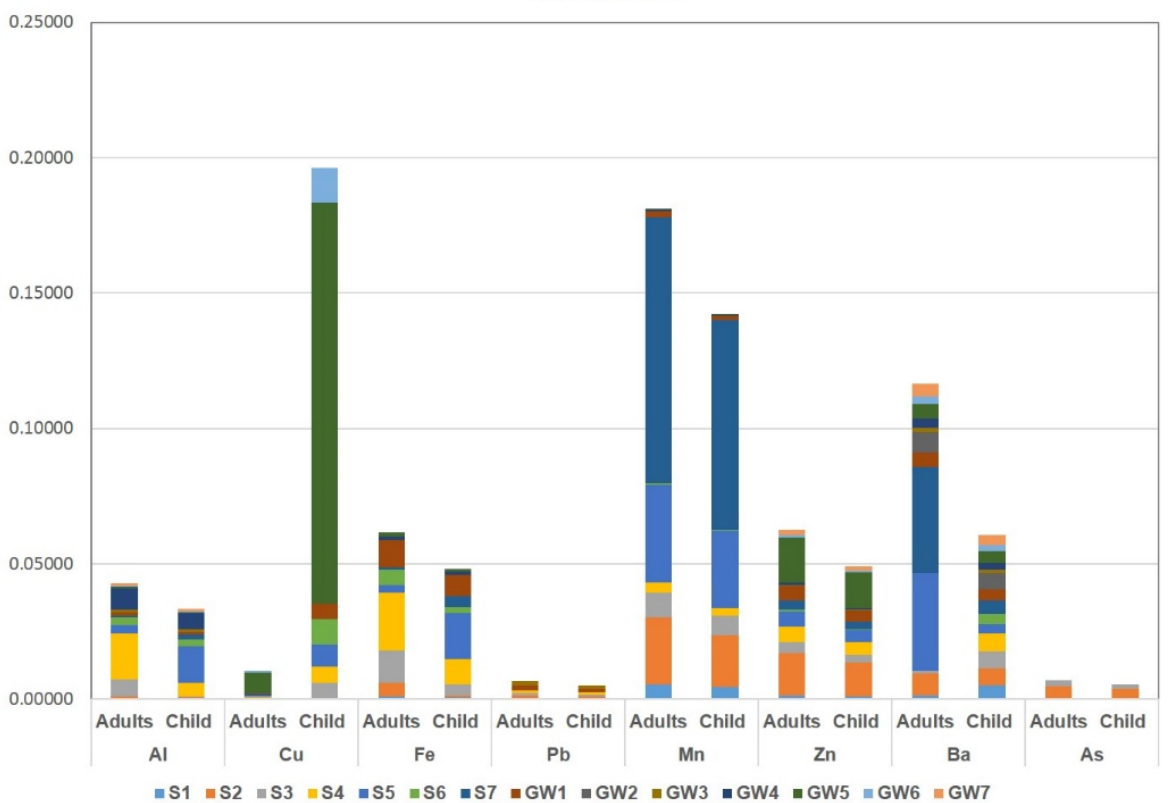

Figure 3. CDI Ingestion values along the sampling sites for each PTE assessed.

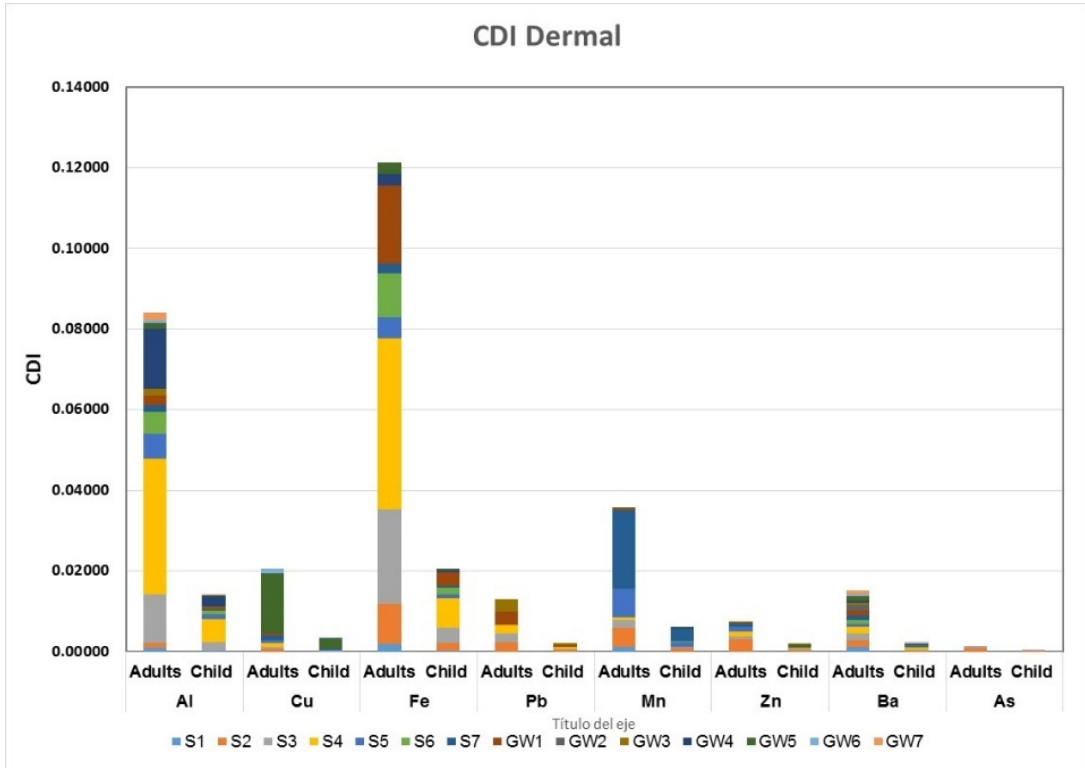

Figure 4. CDI dermal values along the sampling sites for each PTE assessed.

The CDI and HQ dermal values in adults were above the limit 1 for $\mathrm{Al}, \mathrm{Pb}, \mathrm{Mn}$ and As. Specifically, the values with a high impact on the indices for each element and the corresponding samples are as follows: (1) Al in samples S3, S4 and GW4; (2) Pb in samples S2, S3, S4, GW1 and GW3; (3) Mn in samples S1, S2, S3, S5 and S6; and (4) As only in samples S2 and S3. On the other hand, for children the CDI and HQ dermal values were above the limit of 1 for $\mathrm{Pb}, \mathrm{Mn}$, and $\mathrm{Cu}$. The samples GW1 and GW3 were above the limit for $\mathrm{Pb}$; whereas for $\mathrm{Mn}$ were the samples S5, S7; and finally, for Cu only in the sample GW5 (Table 4 and Figure 4). 
Table 4. Chronic daily intake (CDI), hazard quotient (HQ) and hazard index (HI) for adult and child groups for non-carcinogenic risk assessment.

\begin{tabular}{|c|c|c|c|c|c|c|c|c|c|c|c|c|c|c|}
\hline \multicolumn{8}{|c|}{ River Water } & \multicolumn{7}{|c|}{ Groundwater } \\
\hline & & \multirow[b]{2}{*}{ Mean } & \multicolumn{2}{|l|}{ Oral } & \multicolumn{2}{|c|}{ Dermal } & \multirow[b]{2}{*}{ Max } & & \multicolumn{3}{|c|}{ Oral } & \multicolumn{3}{|c|}{ Dermal } \\
\hline & & & Min & Max & Mean & Min & & & Mean & Min & Max & Mean & Min & Max \\
\hline \multicolumn{15}{|c|}{ Adult } \\
\hline \multirow[t]{8}{*}{ HQ } & $\mathrm{Al}$ & 0.0044 & 0.0005 & 0.0171 & 0.8715 & 0.0943 & 3.3710 & HQ & 0.0017 & 0.0000 & 0.0076 & 0.3290 & 0.0000 & 1.5041 \\
\hline & $\mathrm{Cu}$ & 0.0072 & 0.0000 & 0.0132 & 0.0143 & 0.0000 & 0.0259 & & 0.0303 & 0.0000 & 0.1883 & 0.0596 & 0.0000 & 0.3702 \\
\hline & $\mathrm{Fe}$ & 0.0100 & 0.0013 & 0.0307 & 0.0981 & 0.0130 & 0.3017 & & 0.0026 & 0.0000 & 0.0141 & 0.0257 & 0.0000 & 0.1388 \\
\hline & $\mathrm{Pb}$ & 0.1375 & 0.0000 & 0.3536 & 2.2537 & 0.0000 & 5.7946 & & 0.1330 & 0.0000 & 0.4747 & 2.1805 & 0.0000 & 7.7800 \\
\hline & Mn & 1.0599 & 0.0208 & 4.0964 & 5.2114 & 0.1022 & 20.141 & & 0.0189 & 0.0000 & 0.0902 & 0.0930 & 0.0000 & 0.4436 \\
\hline & $\mathrm{Zn}$ & 0.0174 & 0.0016 & 0.0528 & 0.0165 & 0.0004 & 0.0519 & & 0.0123 & 0.0000 & 0.0553 & 0.0012 & 0.0000 & 0.0054 \\
\hline & $\mathrm{Ba}$ & 0.1750 & 0.0000 & 0.5616 & 0.2657 & 0.1760 & 0.3334 & & 0.0628 & 0.0221 & 0.1078 & 0.1765 & 0.0620 & 0.3029 \\
\hline & As & 3.2849 & 0.0000 & 16.400 & 0.6461 & 0.0000 & 3.2255 & & & & & & & \\
\hline $\mathrm{HI}$ & & 4.6963 & 0.0330 & 17.960 & 9.3773 & 0.9090 & 20.610 & $\mathrm{HI}$ & 0.2617 & 0.0588 & 0.6838 & 2.8656 & 0.2214 & 8.8439 \\
\hline \multicolumn{15}{|c|}{ Children } \\
\hline \multirow{8}{*}{ HQ } & $\mathrm{Al}$ & 0.0034 & 0.0004 & 0.0135 & 0.1484 & 0.0161 & 0.5741 & & 0.0013 & 0.0000 & 0.0060 & 0.0560 & 0.0000 & 0.2561 \\
\hline & $\mathrm{Cu}$ & 0.0042 & 0.0000 & 0.0094 & 0.0528 & 0.0000 & 0.0959 & HQ & 0.0238 & 0.0000 & 0.1479 & 0.2207 & 0.0000 & 1.3706 \\
\hline & $\mathrm{Fe}$ & 0.0078 & 0.0010 & 0.0241 & 0.0167 & 0.0022 & 0.0514 & & 0.0021 & 0.0000 & 0.0111 & 0.0044 & 0.0000 & 0.0236 \\
\hline & $\mathrm{Pb}$ & 0.1080 & 0.0000 & 0.2778 & 0.3838 & 0.0000 & 0.9868 & & 0.1045 & 0.0000 & 0.3729 & 0.3713 & 0.0000 & 1.3249 \\
\hline & Mn & 0.8327 & 0.0163 & 3.2183 & 0.8624 & 0.0174 & 3.4299 & & 0.0149 & 0.0000 & 0.0709 & 0.0061 & 0.0000 & 0.0214 \\
\hline & $\mathrm{Zn}$ & 0.0136 & 0.0012 & 0.0415 & 0.0028 & 0.0001 & 0.0088 & & 0.0097 & 0.0000 & 0.0434 & 0.0021 & 0.0003 & 0.0042 \\
\hline & $\mathrm{Ba}$ & 0.0743 & 0.0492 & 0.0932 & 0.0396 & 0.0044 & 0.0568 & & 0.0494 & 0.0173 & 0.0847 & 0.0021 & 0.0003 & 0.0042 \\
\hline & As & 2.5808 & 0.0000 & 12.884 & 0.1100 & 0.0000 & 0.5493 & & & & & & & \\
\hline $\mathrm{HI}$ & & 3.6249 & 0.0873 & 14.102 & 1.6166 & 0.0422 & 3.6014 & HI & 0.2056 & 0.0462 & 0.5372 & 0.6623 & 0.0042 & 1.4523 \\
\hline
\end{tabular}

The hazard index (HI) for ingestion in children ranged from 0.05 to 14.1, with a mean value of 2.04, and for adults 0.03 to 17.96, with mean value 2.48 (Table 4). The HI dermal for adults was more significant than the $\mathrm{HI}$ in children. These values demonstrated a health risk for the use and consumption of river water. HI dermal in adults ranged from 0.22 to 20.61 with a mean value of 6.12 and ranged from 0 to 3.61 with mean 1.14 in children (Table 4). HI dermal values suggest that both adult and child population were significantly affected by PTE presence in river water and groundwater by the notable concentrations of $\mathrm{Al}, \mathrm{Mn}, \mathrm{Pb}$ and As.

Based on the USEPA criteria [27], HI ingestion values in adults and children presented a high health risk in S2, S3, S5 and S7. HI dermal values for adults and children presented high risk in river water and groundwater with high values well above the criteria $(<1)$ in samples S1, S2, S3, S4, S5, S7, GW1, GW3 and GW4 for adults and S2, S3, S4, S5, S7, GW1, GW3 and GW5 for children; the samples either have unusual geological enrichment or are under heavy anthropogenic influence (Figure 5).

The results showed that even though there were not much variability in the HI for children and adults, adults generally seem to be at higher non-cancer risks compared with children. In addition, in both children and adults, dermal contact of EPT in river water poses higher non-cancer risks compared to ingestion values.

Similar values of hazard potentials were reported in the literature [41-45]. The results show that $\mathrm{Al}, \mathrm{Pb}, \mathrm{Mn}$ and As pose a non-cancer risk through the dermal pathway to resident adults and children, while $\mathrm{Mn}$ and As pose a non-cancer risk to residents that use and consume the river water.

Prassad et al. [11] reported higher $\mathrm{HI}$ values for $\mathrm{Mn}, \mathrm{Zn}$ and $\mathrm{Pb}$ in the Ganga River than the reported in the present investigation, suggesting that both the adult and child population were significantly affected. 

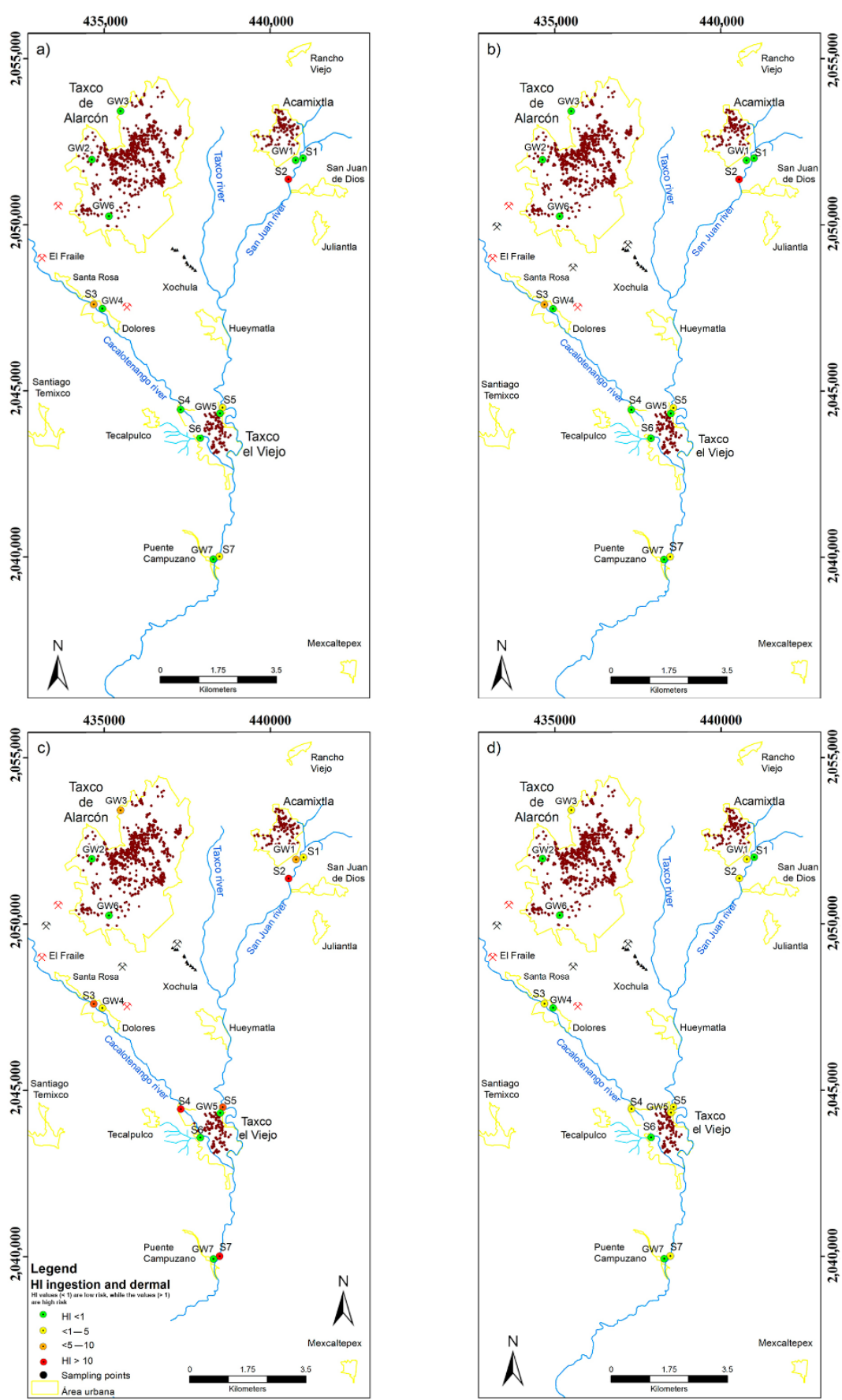

Figure 5. Hazard index (HI) for each site and population group. (a) Adult and (b) child through the ingestion pathway and (c) adult and (d) child through the dermal pathway.

The results from Bodrud-Doza et al. [42] are consistent with this study, which also stated, based on the average values of HQ and HI, that the concentration of PTE might pose little health effects to the adults and children of Dhaka city via oral ingestion. They also reported that HQs of metals were lower than the unity via dermal absorption of groundwaters in Dhaka city, which suggests that these pollutants could pose a minimum hazard to the local residents. However, the calculated mean $\mathrm{HI}$ dermal value for groundwater was 0.0372 , while the same value for surface water was 0.0530 . Thus, it can be inferred that surface water possessed more potential non-carcinogenic harmful health risks to the residents compare to groundwater.

PTE toxicity could be acute, while others could be chronic after long-term exposure, which may lead to the damage of several organs in the body, such as the brain, lungs, liver 
and kidney, causing diseases in the body. Alternative sources of water supply, including sitting of boreholes (after accurate geochemical surveys) for potable water for the community dwellers, should be facilitated.

\subsection{Sediments}

\subsubsection{PTE Concentrations in Sediments}

The concentrations of PTE in sediment samples were contrasted with the TEC, PEC and probable effect level (PEL) values [30-32]. The results are summarized in Table 5. Compared with SQG for aquatic life protection, PTE were above the probable effect level (PEL) for $\mathrm{As}, \mathrm{Zn}$ and $\mathrm{Pb}$ in five samples (71\%), for $\mathrm{Cd}$ in four samples (57.1\%), for $\mathrm{Cu}$ in three samples (42\%) and for $\mathrm{Ni}$ in one sample (14.28). All sites exceeded the TEC levels for $\mathrm{As}, \mathrm{Cd}, \mathrm{Cu}, \mathrm{Pb}$ and $\mathrm{Zn}$, demonstrating a high level of pollution; for $\mathrm{Pb}$, only $\mathrm{S} 1$ was below the TEC value, while in the case of Ni, two sites exceeded the TEC values (S4 and S6). The concentrations of $\mathrm{Ni}$ were below the TEC values for $50 \%$ of the samples, indicating that there are no adverse effects in these samples (S1, S2, S3 and S7 samples). For As and Cu, only two samples exceeded the PEC values (S2 and S3 for arsenic and S1 and S4 for copper). The results also showed values higher than PEC for $\mathrm{Pb}, \mathrm{Zn}$ and $\mathrm{Cd}$ in $57 \%$ of the samples (S3, S4, S5 and S7), indicating that adverse biological effects often can occur (Table 3).

Table 5. The values of the geoaccumulation indices (Igeo) and enrichment factor (EF) of PTE in fluvial sediments in the San Juan-Taxco River system.

\begin{tabular}{|c|c|c|c|c|c|c|c|c|c|c|}
\hline \multicolumn{11}{|c|}{ Geoaccumulation Indices (Igeo) } \\
\hline & S1 & S2 & S3 & S4 & S5 & S6 & S7 & Mean & $\operatorname{Max}$ & Min \\
\hline $\mathrm{Al}$ & -2.87 & -2.88 & -2.7 & -2.59 & -2.68 & -2.41 & -3.34 & -2.787 & -2.41 & -3.34 \\
\hline As & - & 2.45 & 2.76 & 1.82 & 1.78 & - & 1.56 & 2.074 & 2.76 & 1.56 \\
\hline $\mathrm{B}$ & -0.69 & -0.6 & -1 & 0.29 & -0.68 & -0.36 & -0.89 & -0.56 & 0.29 & -0.99 \\
\hline $\mathrm{Ba}$ & -2.61 & -2.64 & -2.4 & -1.76 & -3.18 & -2.72 & -3.42 & -2.681 & -1.76 & -3.42 \\
\hline $\mathrm{Cd}$ & 3.96 & 3.74 & 6.91 & 8.54 & 5.35 & 3.89 & 6.12 & 5.5014 & 8.54 & 3.74 \\
\hline $\mathrm{Co}$ & -2.32 & -2.09 & -1.9 & -1.73 & -1.85 & -1.53 & -2.04 & -1.916 & -1.53 & -2.32 \\
\hline $\mathrm{Cr}$ & -4.79 & -5.79 & - & -4.65 & - & -3.88 & - & -4.778 & -3.88 & -5.79 \\
\hline $\mathrm{Cu}$ & 2.32 & 0.7 & 0.9 & 3.23 & -0.01 & 1.48 & 0.41 & 1.29 & 3.23 & -0.01 \\
\hline $\mathrm{Fe}$ & -2.02 & -1.92 & -1.9 & -1.87 & -1.7 & -1.85 & -1.76 & -1.857 & -1.7 & -2.02 \\
\hline $\mathrm{Mn}$ & -2.33 & -1.68 & -0.6 & 1.22 & -1.8 & -3.47 & -0.81 & -1.346 & 1.22 & -3.47 \\
\hline $\mathrm{Ni}$ & -1.91 & -2.09 & -2.2 & 0.65 & -1.92 & -1.54 & -1.82 & -1.543 & 0.65 & -2.17 \\
\hline $\mathrm{Pb}$ & 0.48 & 1.89 & 3.38 & 3.26 & 2.65 & -0.88 & 2.89 & 1.9529 & 3.38 & -0.88 \\
\hline $\mathrm{Zn}$ & 1.8 & 0.52 & 4.32 & 5.49 & 3.27 & 0.5 & 4.13 & 2.8614 & 5.49 & 0.5 \\
\hline \multicolumn{11}{|c|}{ Enrichment factor (EF) } \\
\hline $\mathrm{Al}$ & 1 & 1 & 1 & 1 & 1 & 1 & 1 & 1 & 1 & 1 \\
\hline As & - & 40.17 & 45.3 & 21.33 & 22.04 & - & 29.92 & 31.742 & 45.25 & 21.33 \\
\hline $\mathrm{B}$ & 4.52 & 4.85 & 3.35 & 7.37 & 4.01 & 4.15 & 5.47 & 4.8171 & 7.37 & 3.35 \\
\hline $\mathrm{Ba}$ & 1.19 & 1.18 & 1.23 & 1.78 & 0.71 & 0.81 & 0.94 & 1.12 & 1.78 & 0.71 \\
\hline $\mathrm{Cd}$ & 113.39 & 98.13 & 801 & 2248 & 261.7 & 78.81 & 704.3 & 615.05 & 2247.9 & 78.81 \\
\hline $\mathrm{Co}$ & 1.46 & 1.73 & 1.85 & 1.81 & 1.78 & 1.84 & 2.46 & 1.8471 & 2.46 & 1.46 \\
\hline $\mathrm{Cr}$ & 0.26 & 0.13 & - & 0.24 & - & 0.36 & - & 0.2475 & 0.36 & 0.13 \\
\hline $\mathrm{Cu}$ & 36.27 & 11.97 & 12.5 & 56.34 & 6.39 & 14.82 & 13.46 & 21.673 & 56.34 & 6.39 \\
\hline $\mathrm{Fe}$ & 1.8 & 1.95 & 1.81 & 1.64 & 1.97 & 1.47 & 2.98 & 1.9457 & 2.98 & 1.47 \\
\hline $\mathrm{Mn}$ & 1.45 & 2.29 & 4.57 & 14.05 & 1.85 & 0.48 & 5.75 & 4.3486 & 14.05 & 0.48 \\
\hline $\mathrm{Ni}$ & 1.93 & 1.73 & 1.49 & 9.48 & 1.69 & 1.83 & 2.87 & 3.0029 & 9.48 & 1.49 \\
\hline $\mathrm{Pb}$ & 10.18 & 27.19 & 69.4 & 57.62 & 40.3 & 2.9 & 74.97 & 40.366 & 74.97 & 2.9 \\
\hline $\mathrm{Zn}$ & 25.46 & 10.55 & 133 & 270.2 & 61.81 & 7.52 & 177.4 & 98.044 & 270.15 & 7.52 \\
\hline
\end{tabular}

\subsubsection{Grain Size}

According to the grain size analysis results of the surface sediments in the San JuanTaxco River system, sand is the overall dominant grain size. At most sites, the sand content exceeds $80 \%$, the contents of gravel and fine particles (clay and silt) were very small 
(averaging 6.25 and $2.38 \%$, respectively). The flow rate and flow velocity of the surface water have high influence of grain size; the textural parameters derived from the grain size analysis reflect the energy conditions in the sedimentation environment. In a low-energy environment, the sediments are fine, although in a high-energy environment, the sediments are coarse [46]. In this analysis, the distribution of grain size explains the high-energy in the stream producing the dominance of sand size particles, in which the water flux is high, and the slope is steep, thereby preventing the sedimentation of fine-grained particles along the stream.

\subsubsection{Sediment Mineralographic Composition}

XRD studies revealed the presence of different minerals as: Quartz, Calcite, Sanidine, Albite, Biotite, Wickenburgite, Lipsconmbite, Phengite, Gypsum and Muscovite. In all the samples, a predominance of Quartz crystals (36 to 51\%) and Calcite (6 to 18\%) were shown by XRD; Albite was present in four samples (11.5 to $19.2 \%)$, while Sanidine was present in three samples (11.8 to $13.9 \%$ ). In the sediment samples, minerals were found that are composed of aluminum oxide and silicon dioxide, such as Albite, Sanidine, Biotite, Muscovite and Wickenburgite. These minerals are by products of igneous and metamorphic rocks, which are generally unstable in earth-surface due to weathering conditions; these minerals are transformed into stable products (crystalline clay minerals, oxides and hydroxides) that largely conserve aluminum and iron [47]. Therefore, the presence of aluminum and iron in sediments in the study area is associated with an anthropogenic origin.

\subsubsection{Degree of PTE Enrichment and Ecological Risk}

Geoaccumulation index (Igeo) values are summarized in Table 5. According to the calculation of each sampling point, the order of the TPE from the Igeo assessed is as follows: $\mathrm{Cd}>\mathrm{Zn}>\mathrm{Pb}>\mathrm{Cu}>\mathrm{As}>\mathrm{Mn}>\mathrm{Ni}>\mathrm{B}>\mathrm{Fe}>\mathrm{Co}>\mathrm{Ba}>\mathrm{Al}>\mathrm{Cr}$. S3 and $\mathrm{S} 4$ are the most critical points by the Igeo (with four metals in the range of heavily to very heavily contaminated). The Igeo values of $\mathrm{Al}, \mathrm{B}, \mathrm{Ba}, \mathrm{Co}, \mathrm{Cr}$ and $\mathrm{Fe}$ at all sampled were less than zero, suggesting that these sites were not polluted. Cd was the metal that presented the highest contamination in all the sampled sites, the sediment samples were grouped in heavily contaminated for S1, S2 and S6, and heavily and extremely contaminated for S3, S4, S5 and S7. Zn, Pb and Cu are the three PTE that have the greatest influence on the contamination of the river sediments, since they present the highest contamination values of the Igeo. In the case of $\mathrm{Zn}$, these Igeo values were classified as uncontaminated to moderately contaminated (S2 and S6), moderately contaminated (S1), moderately to heavily contaminated (S5), heavily to very contaminated (S3 and S7) and extremely contaminated (S4).

Igeo for $\mathrm{Pb}$ were categorized as uncontaminated in $\mathrm{S6}$, uncontaminated to moderately contaminated in S1, moderately contaminated for S2, moderately to heavily contaminated in and S7 and heavily to very contaminated for S3 and S4. For Cu, Igeo values were classified as uncontaminated in S5, uncontaminated to moderately contaminate in S3, S4 and S7, moderately contaminated for S6, moderately to heavily contaminate in S4. The values of Igeo for As were greater than 1 but less than 2 in the samples of S4, S5 and S7, which were classified as moderately contaminated, while the samples S2 and S3 were considered as moderately to heavily contaminated.

The average EF (Table 5) of $\mathrm{Cr}, \mathrm{Ba}, \mathrm{Co}, \mathrm{Fe}$ and $\mathrm{Ni}$ are found to be less than 3 , indicating minor enrichment, although the average enrichment factors of $\mathrm{B}$ and $\mathrm{Mn}$ are found between 3 and 5, suggesting that contaminations are currently not a major concern, although moderate enrichment is indicated. The average EF of $\mathrm{Cu}$ was 21.67, indicating severe enrichment $(10<\mathrm{EF}<25)$. As and $\mathrm{Pb}$ presented very severe enrichment $(25<\mathrm{EF}<50)$ and $\mathrm{Zn}$ and $\mathrm{Cd}$ presented extremely severe enrichment (EF > 50); the average enrichment factors for these PTEs were 31.74, 40.36, 98.04 and 615.05, respectively. The Cd presents extremely high enrichment in all the points evaluated. 
The results of CFs and individual and global PLI are summarized in Table 6. The level of $\mathrm{CF}$ values for each PTE in the sediment was in the order: $\mathrm{Cd}>\mathrm{Zn}>\mathrm{Pb}>\mathrm{Cu}>\mathrm{As}>\mathrm{Mn}$ $>\mathrm{Ni}>\mathrm{Fe}>\mathrm{Co}>\mathrm{Ba}>\mathrm{Cr}$. Among all metals, contamination by $\mathrm{Cd}$ is the highest in all the sediment samples in a range of CF values from 20 to 560 The CF values for Cd were $>6$ in all the sediments samples, indicating very high contamination. The CF values for $\mathrm{Zn}$, $\mathrm{Pb}, \mathrm{Cu}$ and As present very high contamination and considerable contamination. The $\mathrm{CF}$ values for $\mathrm{Al}, \mathrm{Ba}, \mathrm{Co}, \mathrm{Cr}$ and $\mathrm{Fe}$ in all the samples denotes low contamination for all the samples. These results indicated that the contamination is relatively high; there are serious impacts of pollution related to PTE in the Taxco River System coming from abandoned mining tailings, metals processing (jewelry) and untreated sewage.

Table 6. PTE contamination factors (CFs) and pollution load indices (PLIs) for sediments of all sites studied in the San Juan-Taxco River system.

\begin{tabular}{|c|c|c|c|c|c|c|c|c|c|c|c|c|c|c|}
\hline \multirow{2}{*}{ Sites } & \multicolumn{13}{|c|}{ Contamination Factors (CFs) } & \multirow{2}{*}{ PLI } \\
\hline & Al & As & B & $\mathbf{B a}$ & $\mathrm{Cd}$ & Co & $\mathrm{Cr}$ & $\mathrm{Cu}$ & $\mathbf{F e}$ & Mn & $\mathbf{N i}$ & $\mathrm{Pb}$ & Zn & \\
\hline S1 & 0.21 & - & 0.93 & 0.25 & 23.33 & 0.3 & 0.05 & 7.46 & 0.37 & 0.3 & 0.4 & 2.09 & 5.24 & 0.80 \\
\hline S2 & 0.2 & 8.19 & 0.99 & 0.24 & 20 & 0.35 & 0.03 & 2.44 & 0.4 & 0.47 & 0.35 & 5.54 & 2.15 & 0.86 \\
\hline S3 & 0.22 & 10.17 & 0.75 & 0.28 & 180 & 0.42 & - & 2.8 & 0.41 & 1.03 & 0.33 & 15.59 & 29.97 & 2.08 \\
\hline S4 & 0.25 & 5.31 & 1.84 & 0.44 & 560 & 0.45 & 0.06 & 14.04 & 0.41 & 3.5 & 2.36 & 14.35 & 67.3 & 2.83 \\
\hline S5 & 0.23 & 5.15 & 0.94 & 0.17 & 61.11 & 0.42 & - & 1.49 & 0.46 & 0.43 & 0.4 & 9.41 & 14.43 & 1.43 \\
\hline S6 & 0.28 & - & 1.17 & 0.23 & 22.22 & 0.52 & 0.1 & 4.18 & 0.42 & 0.14 & 0.51 & 0.82 & 2.12 & 0.72 \\
\hline S7 & 0.15 & 4.44 & 0.81 & 0.14 & 104.44 & 0.36 & - & 2 & 0.44 & 0.85 & 0.43 & 11.12 & 26.31 & 1.59 \\
\hline Mean & 0.22 & 6.652 & 1.06 & 0.25 & 138.73 & 0.4 & 0.06 & 4.916 & 0.42 & 0.96 & 0.68 & 8.417 & 21.07 & 1.47 \\
\hline Max & 0.28 & 10.17 & 1.84 & 0.44 & 560 & 0.52 & 0.1 & 14.04 & 0.46 & 3.5 & 2.36 & 15.59 & 67.3 & 2.83 \\
\hline Min & 0.15 & 4.44 & 0.75 & 0.14 & 20 & 0.3 & 0.03 & 1.49 & 0.37 & 0.14 & 0.33 & 0.82 & 2.12 & 0.72 \\
\hline
\end{tabular}

In many studies, where the $\mathrm{CF}$ index has been calculated, $\mathrm{CF}$ values ranged from 0.03 to 2.31 for $\mathrm{Cr}, \mathrm{As}, \mathrm{Fe}, \mathrm{Al}, \mathrm{Co}, \mathrm{Ni}, \mathrm{Zn}$ and $\mathrm{Mn}, \mathrm{CF}$ values in the Zarrin-Gol River ranged from 0.14 to 6.08 for $\mathrm{Fe}, \mathrm{Mn}, \mathrm{ZN}, \mathrm{Cr}$ and $\mathrm{Ni}$ and $\mathrm{CF}$ values in the Yauri River ranged from 0.44 to 2.47 for $\mathrm{Cr}, \mathrm{Fe}, \mathrm{Ni}$ and $\mathrm{Zn}[2,7]$.

The PLI values estimated by sampling points ranged from 0.72 to 2.83 (Table 6). These indicate that samples S1, S2 and S6, where PLI was below 1, were unpolluted, the samples S5 and S6 were moderately polluted, while samples S3 and S4 were polluted. For computing the global value, it was necessary to consider all the samples and correct for points S1, S3, S5, S6 and S7, which do not contain As and Cr; therefore, $n=12$. The global value of PLI for the entire study area was 1.29 , which makes it a moderately contaminated area (Figure 6). This indicates that the San Juan, Taxco and Cacalotenango rivers are in a state of contamination due to the influence of the $13 \mathrm{PTEs}$ evaluated, with $\mathrm{Cd}, \mathrm{Zn}, \mathrm{Pb}$ and $\mathrm{Cu}$ being the most influential elements.

The ecological risk of PTE in superficial sediments was assessed through the potential ecological risk index ( $E_{r}^{i}$ and RI) and summarized in Table 7. $E_{r}^{i}$ values for Cd in almost all the samples indicated very high ecological risk (666 to 16,800), except for S2, which was classified as considerable ecological risk (600); for As, the values $E_{r}^{i}$ were classified as moderate ecological risk in samples S4, S5 and S7 (44.38 to 53.1) to appreciable ecological risk in samples S2 and S3 (81.88 to 101.67). For Cr, all the values of $E_{r}^{i}$ in the studied sediments were assessed with low ecological risk.

The $E_{r}^{i}$ values for $\mathrm{Pb}$ showed low ecological risk in samples S1, S2 and S6, and moderate ecological risk in samples S3, S4, S5 and S7. In the case of Cu, the values in almost all the samples showed a low ecological risk, but $\mathrm{S} 4$ showed a moderate ecological risk. The values of RI in all the studied sites were above 600 (RI > 600), which indicated very high ecological risk for the studied area. In summary, the $E_{r}^{i}$ and RI indices for the studied elements in the surface sediment at all sites showed that San Juan, Cacalotenango and Taxco river pose considerable to high potential ecological risk with major contribution of As and Cd (Table 7 and Figure 7). 


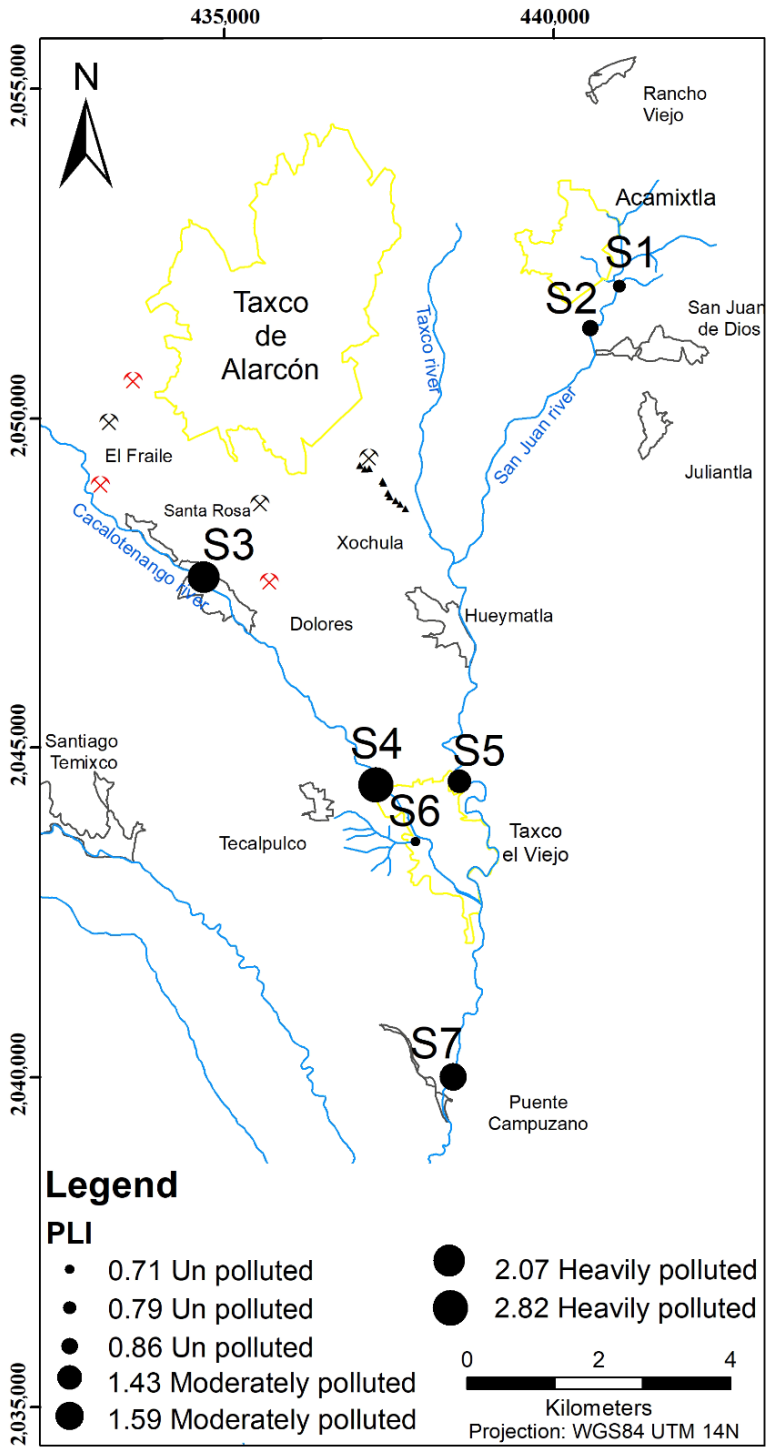

Figure 6. Spatial distribution of the pollution load index (PLI) in fluvial sediments of the San Juan-Taxco River system.

Table 7. Potential ecological risk index in the San Juan-Taxco River system.

\begin{tabular}{|c|c|c|c|c|c|c|c|}
\hline \multirow{2}{*}{ Sites } & \multicolumn{5}{|c|}{$E_{r}^{i}$} & \multirow{2}{*}{ RI } & \multirow{2}{*}{ Risk Grade } \\
\hline & As & $\mathrm{Cd}$ & $\mathrm{Cr}$ & $\mathrm{Cu}$ & $\mathbf{P b}$ & & \\
\hline S1 & & 700 & 0.109 & 37.32 & 10.47 & 747.9 & very high \\
\hline S2 & 81.88 & 600 & 0.054 & 12.2 & 27.71 & 721.83 & very high \\
\hline S3 & 101.67 & 5400 & & 14 & 77.94 & 5593.61 & very high \\
\hline S4 & 53.13 & 16,800 & 0.12 & 70.18 & 71.76 & $16,995.19$ & very high \\
\hline S5 & 51.46 & 1833.3 & & 7.46 & 47.06 & 1939.31 & very high \\
\hline S6 & & 666.7 & 0.204 & 20.89 & 4.09 & 691.85 & very high \\
\hline S7 & 44.38 & 3133.3 & & 9.98 & 55.59 & 3243.28 & very high \\
\hline Mean & 66.504 & 4161.9 & 0.12175 & 24.576 & 42.0886 & 4276.1386 & \\
\hline Max & 101.67 & 16,800 & 0.204 & 70.18 & 77.94 & $16,995.19$ & \\
\hline Min & 44.38 & 600 & 0.054 & 7.46 & 4.09 & 691.85 & \\
\hline
\end{tabular}




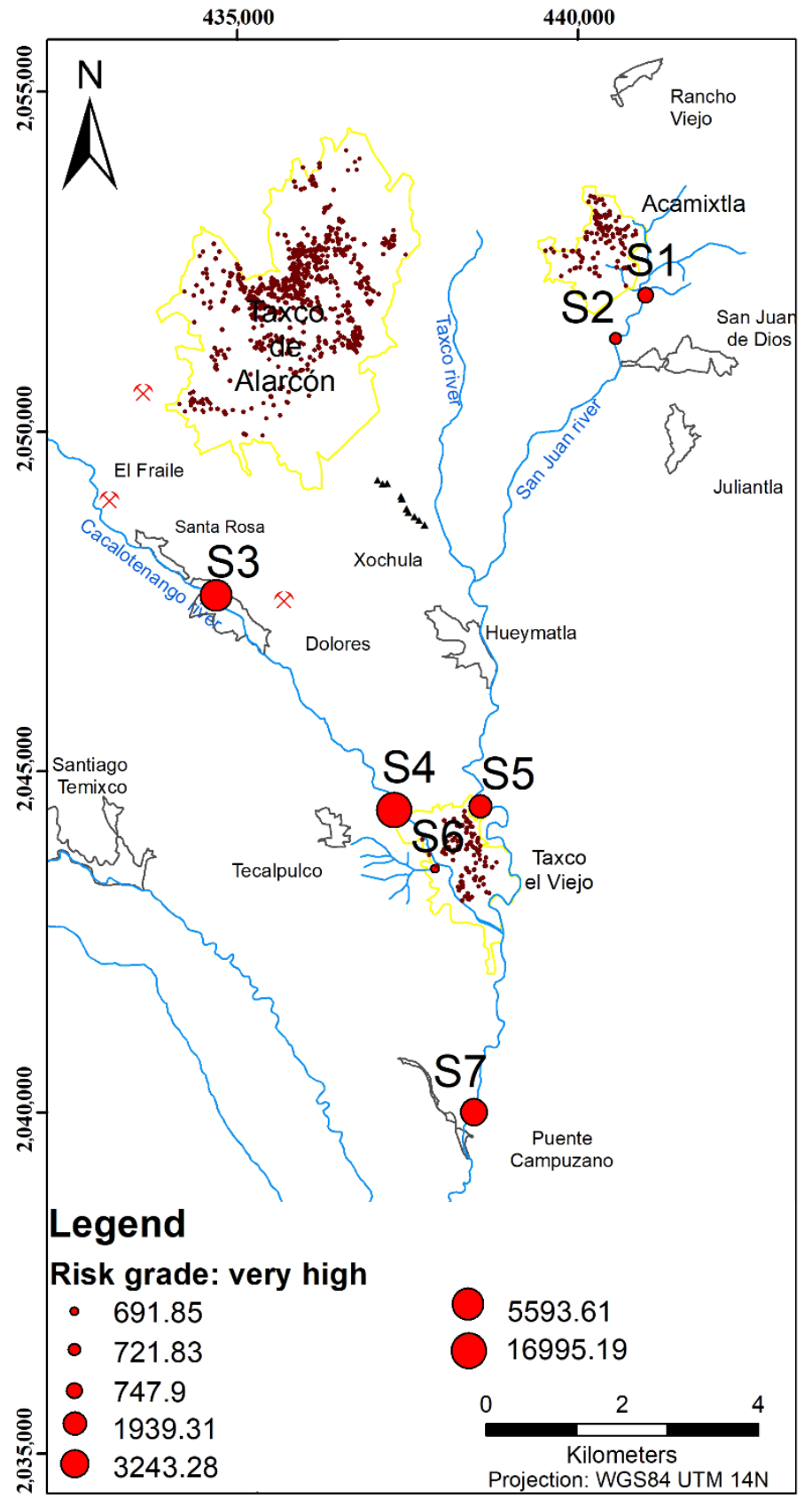

Figure 7. Spatial distribution of the potential ecological risk index in the San Juan-Taxco River system.

Summarizing, the degree of pollution from PTE decreased in the following sequence $\mathrm{Cd}>\mathrm{Zn}>\mathrm{Pb}>\mathrm{As}>\mathrm{Cu}>\mathrm{Mn}>\mathrm{Ba}>\mathrm{Ni}$. It is worth noting that the investigations carried out revealed a considerable loading of the surface sediment with $\mathrm{Cd}$. Consequently, $\mathrm{Cd}, \mathrm{Zn}$ and $\mathrm{Pb}$ may originate from mining, jewelry wastes and agricultural sources, such as pesticides and chemical fertilizers (phosphate fertilizer). The indices exhibited very high pollution in S4 and S3, and considerable contamination in S7 and S5. The results revealed the degree of PTE pollution with PLI in the study area is moderately contaminated and RI values demonstrated very high ecological risk for the five metals assessed ( $\mathrm{As}, \mathrm{Cd}, \mathrm{Cr}, \mathrm{Cu}$ and $\mathrm{Pb}$ ).

The concentrations of PTEs in the San Juan-Taxco River system were compared with other major polluted rivers in Mexico and worldwide and summarized in the Table 8. The comparison of the PTEs concentrations with other Mexican rivers showed that this system presents higher concentrations of $\mathrm{As}, \mathrm{Cd}, \mathrm{Ni}, \mathrm{Fe}, \mathrm{Cu}$ and $\mathrm{Zn}$ than those reported in the 
Atoyac river; $\mathrm{Cd}, \mathrm{Cu}$ and $\mathrm{Zn}$ higher than those reported in the Panuco River and exceeds the concentrations of $\mathrm{As}, \mathrm{Fe}, \mathrm{Cu}, \mathrm{Ni}$ and $\mathrm{Zn}$ measured in the Coatzacoalcos River $[4,48,49]$.

Table 8. Comparison of PTE concentrations with other riverine environments worldwide.

\begin{tabular}{|c|c|c|c|c|c|c|c|c|c|}
\hline \multirow{2}{*}{ PTE } & As & Ba & $\mathrm{Cd}$ & $\mathrm{Cr}$ & $\mathrm{Cu}$ & $\mathrm{Ni}$ & $\mathrm{Pb}$ & Zn & $\mathrm{Fe}$ \\
\hline & \multicolumn{9}{|c|}{$\left(\mathrm{mg} \mathrm{kg}^{-1}\right)$} \\
\hline Present study & $17.1-48.8$ & & $1.8-50.4$ & $2.5-17.1$ & $4.3-502$ & $15.4-111$ & $2.5-13.9$ & $45.09-142$ & $15,366-23,223$ \\
\hline Yangtze River [50] & 9.1 & & 0.19 & 79.1 & 24.7 & 31.9 & 23.8 & 82.9 & - \\
\hline Yellow River [51] & - & & $0.1-0.3$ & $61.3-139.5$ & $14.1-30.3$ & $19.3-34.6$ & $15.5-24.6$ & $39.9-74.6$ & - \\
\hline Tinto River [52] & 1130 & & 2.75 & 56 & 805 & 17 & 2230 & 901 & 11,500 \\
\hline Tigris River [53] & & & 7.9 & - & 2860 & & 66 & 1061 & - \\
\hline Ganga River [54] & - & & 1.7 & 69.9 & 29.8 & 372 & 26.7 & 67.8 & $31,988.60$ \\
\hline Euphrates River [55] & - & & 1.9 & 58.9 & 18.9 & 67.1 & 22.6 & 48 & 2249.50 \\
\hline Zarrin-Gol River [7] & 21.91 & & - & 37.67 & - & 12.39 & - & 32.68 & 13,751 \\
\hline
\end{tabular}

\subsubsection{Comparison of PTE Concentrations with Other Riverine Environments Worldwide}

The worldwide comparison showed higher concentrations, the comparison with Zarrin-Gol River in Iran in As, $\mathrm{Ni}, \mathrm{Zn}$ and $\mathrm{Fe}$, and the sediment concentrations of $\mathrm{Cd}, \mathrm{Cu}$, $\mathrm{Ni}, \mathrm{Pb}$ and $\mathrm{Zn}$ in the present study exceed those reported in the Yantze, Yellow, Ganga and Euphrates Rivers [7,48,55]. The concentration of Fe was found to be higher than the values in the Tinto River and Euphrates River (Table 8). The Fe abundance in sediments has been attributed to weathering, erosion and other natural sources, as well as large-scale human activities (mining release, municipal solid waste and agricultural activities).

Cadmium values are considerably high, compared to the other rivers of Mexico and the world; the results showed concentrations in all study sites to be above the background values, and these vales are associated with wastes from mining and urban and agricultural runoff. The concentration of $\mathrm{Pb}$ in this study was found to be lower than the concentration reported in the Atoyac, Panuco, Coatzacoalcos, Yangtze, Yellow, Tinto, Ganga and Euphrates Rivers [7,48-55]. This metal is mainly associated with Fe oxide fraction and shows high retention in sediments. $\mathrm{Pb}$ and $\mathrm{Zn}$ concentrations is attributed that tailings are being washed down by the action of rain towards the riverbed. $\mathrm{Zn}$ is one of the most abundant elements in the sediment of the San Juan-Taxco River system (Table 8). Those values are higher than the values reported in the Atoyac, Panuco, Coatzacoalcos, Yangtze, Yellow, Ganga, Euphrates and Zarrin Rivers [7,48-55].

The results of PTE pollution in surface sediments of the San Juan-Taxco River system indicated that the contamination is relatively high. Several authors have documented the contamination until the closure of the mines and after the abandonment of the mining tailings [14,15,56,57]; the closure of the mines brought with it an increase in formal and informal crafts and jewelry workshops not only made of silver, but also of other alloys, such as alpakar, brass and tumbaga. The results indicate that the concentrations previously reported in the sediments do not coincide in order of abundance or in the same elements; in this work, the toxic elements present in order of abundance are $\mathrm{Cd}>\mathrm{Zn}>\mathrm{Pb}>\mathrm{Cu}>\mathrm{As}$ and before they were $\mathrm{Pb}>\mathrm{As}>\mathrm{Zn}>\mathrm{Fe}[17,56]$.

The manufacturing process of handicrafts and handmade jewelry include refining and alloying with other metals, such as $\mathrm{Cd}, \mathrm{Zn}$ and $\mathrm{Cu}$, the smelting process, framing the metals, soldering, platinating, polishing or etching the piece. Each task is generally accomplished by the use of some substances and actives of PTEs, such as Cd, Zn and Ni; traditionally, $\mathrm{Cd}$ and $\mathrm{Zn}$ have been used in jewelry solders or galvanized [20]. The rivers in the mining region of Taxco constantly receive trace amount of PTEs from weathering of rocks. Continuous or intermittent but relatively higher input of heavy metals to rivers and streams is linked to anthropogenic sources [56].

The release of PTE may change between different points depending on the local concentrations and physicochemical conditions and the sources. The contributions of these elements can be from the piles of mining tailings dust, the discharges of the municipal network and water contributions from the jewelry and handicraft workshops, the dust 
produced by the metal processing of these workshops and pollution from regular municipal discharges. These toxic elements may be mobilized by rain and air towards the riverbed.

\section{Conclusions}

PTEs in water resources is a severe threat due to their toxic nature and tendency to bio-accumulate and amplify in higher trophic levels, altering the ecological functions of the river and soil, poisoning the aquatic environment and putting at risk the populations dependent on the river system. This study determined the concentrations of nine PTEs in water samples; the concentrations in water (river water and groundwater) in almost all of the samples were below the standards of the $\mathrm{WHO}$. The concentrations of $\mathrm{Mn}, \mathrm{As}, \mathrm{Al}$ and $\mathrm{Pb}$ in water posed health risks based on the CDI, HQ and HI method and USEPA criteria (2005). The human health risk assessment indicated that the water of San Juan-Taxco River system is not recommended for human consumption, domestic activities and prolonged ingestion.

The San Juan-Taxco River system has a potential health risk in both population groups for the two pathways. Non-healthy risk was determined in groundwater; the risk to human health in the river water can be attributed to the dissolution of minerals, trace metals from direct sewage discharge, agricultural runoff, tailings dams and increasing concentration due to bioaccumulation downstream. Therefore, it can be established that the population living in the riverine landscape and using untreated surface water for drinking are vulnerable to the health risk from TPE pollution. Proper monitoring in the area should be implemented to control the pollution and to identify alternative sources of drinking water. It is recommended to implement a proper treatment and management policies of water to reduce the health risk.

Anthropogenic sources have contributed significantly to PTE concentrations in the study area, while natural sources have contributed only small amounts. $\mathrm{Cd}, \mathrm{Zn}$ and $\mathrm{Pb}$ may originate from mining and jewelry wastes, wastewater and agricultural sources, such as pesticides and chemical fertilizers. The analyses also indicate that the main processes that control the pollution are mining tailings erosion with discharge processes and proportional dilution related to grain-size distribution processes (this is a high-energy stream with dominance of sand size particles). Thus, PTE concentrations tend to accumulate in banks and in backwaters with fine sediments with reduced flow rate and flow velocity.

PTE concentration in water and sediments pose a severe threat to the human population due to erratic disposal and rapid discharge of PTE in the river environment by mining tails, numerous jewelry workshops and human settlements in this riverine landscape.

This study provides the environmental knowledge in identifying the contaminants in the sedimentological substrate and locates the sites in need of immediate assistance. In addition, it is necessary to identify the number of handicrafts and jewelry workshops and to know the amount of PTE waste that is generated.

It is also very important to establish the PTE waste concentration in water and the environment to establish regulation, conservation and treatment measures. The information generated from the present study would serve to establish public policies for an effective management of this fluvial system in Mexico. Moreover, sensitization and awareness of the health risk of the consumption of water sources affected with PTE should be carried out intensively.

To reinforce the results of this study, it is recommended to increase the number of samples in those critical areas. Future research should include the risk analysis of the entire population. An isotopic analysis of strontium could provide a more detail source of contaminants.

Author Contributions: E.R.S.S.-sampling collection, data analysis, geochemical assessment and paper writing and editing; M.M.M.-Statistical analysis and paper writing and editing; J.M.E.M.-sampling collection, map editing and paper editing; M.V.E.A.—data analysis, geochemical assessment and paper writing; O.T.M.-laboratory analysis and paper editing. All authors have read and agreed to the published version of the manuscript. 
Funding: This research received financial support from the Project Semilla of the Autonomous University of Guerrero (UAGro).

Acknowledgments: We thank the support of the Mexican Institute of Water Technology (IMTA) for the grain size analysis. We thank the Geochemistry and Soil physics laboratories of Autonomous University of Guerrero for the support of the field and laboratory analysis.

Conflicts of Interest: The authors have no conflict of interest to declare.

\section{References}

1. Liu, J.; Yin, P.; Chen, B.; Gao, F.; Song, H.; Li, M. Distribution and contamination assessment of heavy metals in surface sediments of the Luanhe River Estuary, northwest of the Bohai Sea. Mar. Pollut. Bull. 2016, 109, 633-639. [CrossRef] [PubMed]

2. Malvandi, H. Preliminary evaluation of heavy metal contamination in the Zarrin-Gol River sediments, Iran. Mar. Pollut. Bull. 2017, 117, 547-553. [CrossRef] [PubMed]

3. Rodriguez-Espinosa, P.; Shruti, V.; Jonathan, M.; Tavera, E.M. Metal concentrations and their potential ecological risks in fluvial sediments of Atoyac River basin, Central Mexico: Volcanic and anthropogenic influences. Ecotoxicol. Environ. Saf. 2018, 148, 1020-1033. [CrossRef]

4. Morales-García, S.; Rodríguez-Espinosa, P.; Shruti, V.; Jonathan, M.; Martínez-Tavera, E. Metal concentrations in aquatic environments of Puebla River basin, Mexico: Natural and industrial influences. Environ. Sci. Pollut. Res. 2016, 24, $2589-2604$. [CrossRef]

5. Singh, U.K.; Kumar, B. Pathways of heavy metals contamination and associated human health risk in Ajay River basin, India. Chemosphere 2017, 174, 183-199. [CrossRef]

6. $\quad$ Loredo-Portales, R.; Bustamante-Arce, J.; González-Villa, H.N.; Moreno-Rodríguez, V.; Del Rio-Salas, R.; Molina-Freaner, F.; González-Méndez, B.; Archundia-Peralta, D. Mobility and accessibility of $\mathrm{Zn}, \mathrm{Pb}$, and As in abandoned mine tailings of northwestern Mexico. Environ. Sci. Pollut. Res. 2020, 27, 26605-26620. [CrossRef]

7. Hidayati, N.V.; Asia, L.; Khabouchi, I.; Torre, F.; Widowati, I.; Sabdono, A.; Doumenq, P.; Syakti, A.D. Ecological risk assessment of persistent organic pollutants (POPs) in surface sediments from aquaculture system. Chemosphere 2020, 263, 128372. [CrossRef]

8. Wang, X.; Cui, L.; Li, J.; Zhang, C.; Gao, X.; Fan, B.; Liu, Z. Water quality criteria for the protection of human health of 15 toxic metals and their human risk in surface water, China. Environ. Pollut. 2021, 276, 116628. [CrossRef]

9. Wang, X.; Fan, B.; Fan, M.; Belanger, S.; Li, J.; Chen, J.; Gao, X.; Liu, Z. Development and use of interspecies correlation estimation models in China for potential application in water quality criteria. Chemosphere 2020, 240, 124848. [CrossRef]

10. Łuczyńska, J.; Paszczyk, B.; Łuczyński, M.J. Fish as a bioindicator of heavy metals pollution in aquatic ecosystem of Pluszne Lake, Poland, and risk assessment for consumer's health. Ecotoxicol. Environ. Saf. 2018, 153, 60-67. [CrossRef]

11. Prasad, S.; Saluja, R.; Joshi, V.; Garg, J.K. Heavy metal pollution in surface water of the Upper Ganga River, India: Human health risk assessment. Environ. Monit. Assess. 2020, 192, 742. [CrossRef] [PubMed]

12. Siddiqui, E.; Pandey, J. Assessment of heavy metal pollution in water and surface sediment and evaluation of ecological risks associated with sediment contamination in the Ganga River: A basin-scale study. Environ. Sci. Pollut. Res. 2019, 26, 10926-10940. [CrossRef] [PubMed]

13. Corami, F.; Morabito, E.; Gambaro, A.; Cescon, P.; Libralato, G.; Picone, M.; Ghirardini, A.V.; Barbante, C. Geospeciation, toxicological evaluation, and hazard assessment of trace elements in superficial and deep sediments. Environ. Sci. Pollut. Res. Int. 2020, 27, 15565-15583. [CrossRef] [PubMed]

14. Dótor, A.A.; Armienta, M.A.; Arcega, F.; Talavera, M.O. Procesos de transporte de arsénico y metales en aguas superficiales del distrito minero de Taxco, Mexico: Aplicación de isótopos estables (Transport processes of arsenic and metals in surface waters in the mining district of Taxco, Mexico). Hidrobiológica 2014, 24, 256.

15. Dótor, A.; Armienta, H.M.; Talavera, M.O.; Ruiz, J. Geochemical behavior of $\mathrm{Cu}$ and sulfur isotopes in the tropical mining region of Taxco, Guerrero (southern Mexico). Chem. Geol. 2017, 471, 1-12. [CrossRef]

16. Talavera, M.O.; Ruiz, J.; Díaz, V.E.; Ramírez, G.A.; Cortés, A.; Salgado SS, A.; Rivera, B.R. Water-rock-tailings interactions and sources of sulfur and metals in the subtropical mining region of Taxco, Guerrero (Southern Mexico): A multi-isotopic approach. Appl. Geochem. 2016, 66, 73-81. [CrossRef]

17. Árcega-Cabrera, F.; Armienta, M.A.; Daesslé, L.W.; Castillo-Blum, S.E.; Talavera, O.; Dótor, A. Variations of Pb in a mine-impacted tropical river, Taxco, Mexico: Use of geochemical, isotopic and statistical tools. Appl. Geochem. 2009, 24, 162-171. [CrossRef]

18. Vázquez, B.A.; Talavera, M.O.; Moreno, G.M.; Salgado, S.S.; Ruiz, J.; Huerta, B.G. Source apportionment of lead in the blood of women of reproductive age living near tailings in Taxco, Guerrero, Mexico: An isotopic study. Sci. Total Environ. 2017, 583, 104-114. [CrossRef]

19. INEGI. Censo y Conteos de Población y Vivienda of Guerrero; INEGI: Mexico City, Mexico, 2020.

20. Clausell, A.M. Historia de la Plata Mexicana; AAPAUNAM Academia, Ciencia y Cultura: Mexico City, Mexico, 2010; Volume II, pp. 24-34. Available online: https:/ / medigraphic.com/pdfs/aapaunam/pa-2010/pa101f.pdf (accessed on 7 June 2021).

21. INEGI. La Minería en México; Serie estadísticas sectoriales No. 24; INEGI: Mexico City, Mexico, 2010.

22. Ramírez, M. Acuerdos Comunitarios Para la Realización del Programa de Saneamiento de las Aguas Residuales de la Microcuenca del Río San Juan Taxco; Pueblo Sa-bio AC: San Juan de Dios, Guerrero, Mexico, 2013. 
23. Romero, F.M.; Armienta, M.A.; González-Hernández, G. Solid-phase control on the mobility of potentially toxic elements in an abandoned lead/zinc mine tailings impoundment, Taxco, Mexico. App. Geochem. 2007, 22, 109-127. [CrossRef]

24. CONAGUA. Actualización de la Disponibilidad Media Anual de Agua en el Acuífero de Iguala Estado de Guerrero. México: Comisión Nacional del Agua. DOF, 20 de abril de 2015. Available online: https:/ / www.gob.mx/cms/uploads/attachment/file/10 3668/DR_1205.pdf (accessed on 23 December 2021).

25. Tessier, A.; Campbell, P.G.C.; Bisson, M. Sequential Extraction Procedure for the Speciation of Particulate Trace Metals. Anal. Chem. 1979, 51, 844-851. [CrossRef]

26. ASTM D2487-06; Standard Practice for Classification of Soils for Engineering Purposes (Unified Soil Classification System); ASTM International: West Conshohocken, PA, USA, 2006.

27. USEPA. Guidelines for Carcinogen Risk Assessment; EPA/630/P-03/001F; Risk Assessment Forum: Washington, DC, USA, 2005.

28. USEPA. Exposure Factors Handbook; EPA/600/R-09/052F; National Center for Environmental Assessment: Washington, DC, USA, 2011. Available online: http://www.epa.gov/ncea/efh (accessed on 15 October 2021).

29. WHO. Guidelines for Drinking-Water Quality, 3rd ed.; Incorporating 1st and 2nd Addenda; WHO: Geneva, Switzerland, 2008; Volume 1.

30. Canadian Council of Ministers of the Environment CCME. Canadian Environmental Quality Guidelines; CCME: Winnipeg, MB, Canada, 1999.

31. Environmental Protection Agency. 2015. Available online: https://www.epa.gov/sites/production/files/2015-09/documents/r3 _btag_fw_sediment_benchmarks_8-06.pdf (accessed on 4 September 2021).

32. Macdonald, D.D.; Ingersoll, C.G.; Berger, T.A. Development and evaluation of Consensus-Based Sediment Quality Guidelines for freshwater ecosystems. Arch. Environ. Contam. Toxicol 2000, 39, 20-31. [CrossRef] [PubMed]

33. Müller, G. Index of geoaccumulation in sediments of the Rhine River. Geo. J. 1969, 2, 108-118.

34. Varol, M. Assessment of heavymetal contamination in sediments of the Tigris River (Turkey) using pollution indices and multivariate statistical techniques. J. Hazard. Mater. 2011, 195, 355-364. [CrossRef] [PubMed]

35. Rudnick, R.L.; Gao, S. Composition of the Continental Crust. Treatise Geochem. 2014, 3, 1-64. [CrossRef]

36. Barats, A.; Renac, C.; Orani, A.M.; Durrieu, G.; Saint Martin, H.; Esteller, A.M.; Garrido, H.S. Tracing source and mobility of arsenic and trace elements in a hydrosystem impacted by past mining activities (Morelos state, Mexico). Sci. Total Environ. 2019, 712, 135565. [CrossRef]

37. Sakan, S.M.; Đorđević, D.S.; Manojlović, D.D.; Predrag, P.S. Assessment of heavy metal pollutants accumulation in the Tisza river sediments. J. Environ. Manag. 2009, 90, 3382-3390. [CrossRef]

38. Al Rashdi, S.; Arabi, A.A.; Howari, F.M.; Siad, A. Distribution of heavy metals in the coastal area of Abu Dhabi in the United Arab Emirates. Mar. Pollut. Bull. 2015, 97, 494-498. [CrossRef]

39. Hakanson, L. An ecological risk assessment index for aquatic contamination control, a sedimentological approach. Water Res. 1980, 14, 975-1001. [CrossRef]

40. Tomlinson, D.L.; Wilson, J.G.; Harris, C.R.; Jeffrey, D.W. Problems in the assessment of heavy-metal levels in estuaries and the formation of a pollution index. Helgol. Meeresunters. 1980, 33, 566-575. [CrossRef]

41. Hadzi, G.Y.; Essumang, D.K.; Ayoko, G.A. Assessment of contamination and health risk of heavy metals in selected water bodies around gold mining areas in Ghana. Environ. Monit. Assess. 2018, 190, 406. [CrossRef]

42. Bodrud-Doza, M.; Didar-Ul Islam, S.M.; Rume, T.; Quraishi, S.B.; Rahman, M.S.; Bhuiyan, M.A.H. Groundwater quality and human health risk assessment for safe and sustainable water supply of Dhaka City dwellers in Bangladesh Groundw. Sustain. Dev. 2020, 10, 100374. [CrossRef]

43. Armah, F.A.; Gyeabour, E.K. Health risks to children and adults residing in riverine environments where surficial sediments contain metals generated by active gold mining in Ghana. Toxicol. Res. 2013, 29, 69-79. [CrossRef] [PubMed]

44. Nkoom, M.; Jerry, S.C.; Michael, K. Assessment of endocrine disrupting trace metals in river Samre at Samreboi in the Wassa Amenfi West District of the western region of Ghana. J. Water Resour. Prot. 2013, 5, 983-992. [CrossRef]

45. Obasi, P.N.; Akudinobi, B.B. Potential health risk and levels of heavy metals in water resources of lead-zinc mining communities of Abakaliki, southeast Nigeria. Appl. Water Sci. 2020, 10, 184. [CrossRef]

46. Kim, S.; Lee, K.C.; Kim, J.E.; Jung, K.Y.; Ahn, J.M.; Kim, H.G.; Lee, I.J.; Shin, D.S.; Yang, D.S. Change in geochemical characteristics of surface sediments in the Nakdong river main stream. J. Environ. Sci. Int. 2017, 26, 311-324. [CrossRef]

47. Farmer, V.C. Sources and speciation of aluminium and silicon in natural waters. Ciba Found. Symp. 1986, 121, 4-23. [CrossRef]

48. Jonathan, M.P.; Roy, P.D.; Rodríguez-Espinosa, P.F.; Sarkar, S.K.; Muñoz-Sevilla, N.P.; Navarrete-López, M.; Srinivasalu, S.; Thangadurai, N. Evaluation of trace element concentration (acid leachable) in sediments from River Pánuco and its adjacent lagoon areas, NE México. Environ. Earth Sci. 2012, 68, 2239-2252. [CrossRef]

49. Ruiz-Fernández, A.C.; Sanchez-Cabeza, J.A.; Alonso-Hernández, C.; Martínez-Herrera, V.; Pérez-Bernal, L.H.; Preda, M.; HillaireMarcel, C.; Gastaud, J.; Quejido-Cabezas, A.J. Effects of land use change and sediment mobilization on coastal contamination (Coatzacoalcos River, Mexico). Cont. Shelf Res. 2012, 37, 57-65. [CrossRef]

50. Wang, H.T.; Wang, J.W.; Liu, R.M.; Yu, W.W.; Shen, Z.Y. Spatial variation, environmental risk and biological hazard assessment of heavy metals in surface sediments of the Yangtze River estuary. Mar. Pollut. Bull. 2015, 93, 250-258. [CrossRef] 
51. Ma, X.L.; Zuo, H.; Tian, M.J.; Zhang, L.Y.; Meng, J.; Zhou, X.N.; Min, N.; Chang, X.Y.; Liu, Y. Assessment of heavy metals contamination in sediments from three adjacent regions of the of the Yellow River using metal chemical fractions and multivariate analysis techniques. Chemosphere 2015, 144, 264-272. [CrossRef]

52. García, J.; Aguado, J.; Morillo, I. Heavy metals in sediments from the Tinto River (Spain). Mine Water Environ. $2012,1,243-246$.

53. Varol, M.; Sen, B. Assessment of nutrient and heavy metal contamination in surface water and sediments of the upper Tigris River, Turkey. Catena 2012, 92, 1-10. [CrossRef]

54. Pandey, J.; Singh, R. Heavy metals in sediments of Ganga River: Up- and downstream urban influences. Appl. Water Sci. 2017, 7,669-1678. [CrossRef]

55. Salah, E.A.M.; Zaidan, T.A.; Al-Rawi, A.S. Assessment of heavy metals pollution in the sediments of Euphrates River, Iraq. J. Water Res. Prot. 2012, 4, 1009-1023. [CrossRef]

56. Armienta, M.A.; Talavera, O.; Villaseñor, G.; Espinosa, E.; Pérez-Martínez, I.; Cruz, O.; Ceniceros, N.; Aguayo, A. Environmental behaviour of metals from tailings in shallow rivers: Taxco, central Mexico. Appl. Earth Sci. 2004, 113, B76-B82. [CrossRef]

57. Talavera, M.O.; Moreno, T.R.; Dotor-Almazán, A.; Flores-Mundo, N.; Duarte Gutiérrez, C. Mineralogy and geochemistry of sulfide-bearing tailings from silver mines in the Taxco, Mexico Area to evaluate their potential environmental impact. Geofís. Int. 2005, 44, 49-64. [CrossRef] 